$-r_{-}$

تأثير برنامج إرشادى على بعض المتنيرات البننية والمهارية في الكرة الطائرة وخفض حدة السلوك العدوانى لاى الأطفال المعاقين ذهنيا القابلين للتُعلم

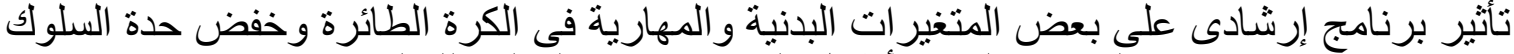
العدو انى لدى الأطفال المعاقين ذهنيا القابلين للتعلم

"م.د// ريبع السيد السيد سراج

المقدمـة ومشكلة البحث:

تعتبر مشكلة الإعاقة العقلية من المشكلات القديمة والتي يهتم بها علماء النفس والتربية والاجتماع والصحة النفسية، كما أنها ظاهرة معقدة الجوانب وتحتاج إلى جهد الكثيرين من القائمين على تتشئة ورعاية المعاقين عقلياً، وهذه الرعاية أمر ضروري لاعتبارات كثيرة، أولها الاعتبار الديني والأخلاقي

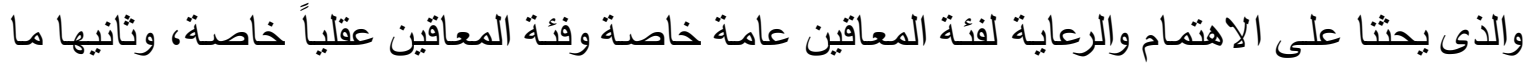
يحقق إتاحة الفرصة للمعاق للتعليم شأنه في ذلك شأن الفرد العادى، أما الاعتبار الثالث فهو مواكبة العالم في الاهنمام بالمعاقين، ثم يأتي الاعتبار الرابع وهو الاعتبار الاقتصادى والذى يتمنل في أن تربية

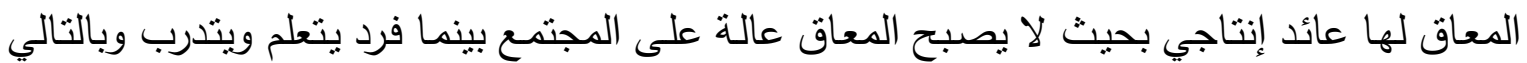
ينتج، إذا أخذنا في الاعتبار أن فئة المعاقين عقليا نسبة لها وزنها في المجتمع. ونظراً للقدرات المحدودة لهؤلاء الأطفال المعاقين عقليا التي لا تسمح لهح بالاستفادة الكاملة من ون الأنشطة التي يمارسها غيرهم من الأطفال العاديين، فإنهم أيضاً يحتاجون نوعا خاصـا من الرعاية تساعدهم على استتمار تلك القدرات المحدودة إلى أقصى حد ممكن، وتلعب عملية علاج المعاقين عقلياً دوراً كبيراً في تحسين ظروفهم الحياتية بحيث تتاح لهم فرص الاستفادة من الفرص التدريبية والتربوية التي وني تمكنهم من التكيف في المؤسسات الفكرية الخاصة بهم ومع زملائهج، وذلك من خلال البرامج الإرشادية باللعب والتي تعتبر المتنفس الوحيد عن انفعالاتهم، والتخفيف من المشاكل السلوكية التي يتعرض لها

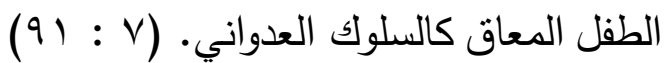
ويرى عصام محمد العقاد (V . . . r. أن الأطفال المعاقين ذهنيا لا تقتصر مشكلاتهم على نقص الكفاءة العقلية، ولكنهم يعانون أيضاً من عدة مشكلات سلوكية وانفعالية نتيجة لما يتعرضون لله من ظروف اجتماعية ونفسية وتربوية غير ملائمة خلال مراحل حياتهم وتتشئتهم، لذا يعتبر العلاج النفسى الجماعى باللعب برنامجاً علاجياً للتخفيف من حدة السلوك العدوانى للأطفال المعاقين ذهنياً والقابلين

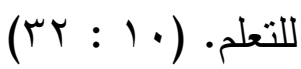

ويؤكد جابر عبد الحميل وعلاء الدين كفافى (ع . . بم) على أهمية الأساليب العلاجية القائمة

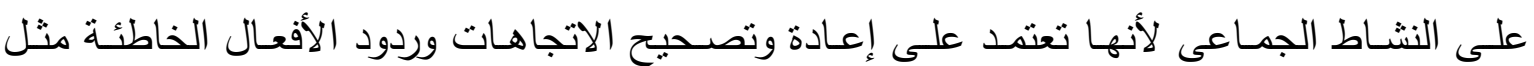
الانطوائية والخجل والسلوك العدوانى، وذلك من خـلا إتاحة الفرصـة للطفل المضطرب سلوكياً فى التى المشـاركة الفعالـة فى جماعـة الأقران التى تمـارس هوايـات وألعـاب مسلية وتعمل فـى جو مـن الود والطمأنينة المصحوب بالتسامح وعد التهديد، مما يتيح الفرصة الكاملة أمام الأطفال المضربين سلوكياً التخفيف من حدة السلوك العدوانى والتوتر والمشاعر غير السوية لديهم، وذلك من خـلا اختيار طرق

مدرس بقسم المنازلات والرياضات المائية بكلية التربية الرياضية جامعة مدينة السادات

مجلة بحوث التربية الثاملة ـ كلية التربية الرياضية للبنات- جامعة الزقازيق ـ المجلد الثانيـ للنصف الأول للأبحاث العلميةـ 1 1 ـ rم 
$-r V-$

تأثير برنامج إرشادى على بعض المتغيرات البلنية والمهارية في الكرة الطائرة وخفض حدة السلوك العدوانى لاى الأطفال المعاقين ذهنيا القابلين للتعلم وأسـاليب جديدة فى التعامل مـع الآخرين والتذوق التدريجى لخبرة الإشباع من خـلال العمل الخـلاق والتقاعل السوى. (r :

تعلم المهارات الأساسية في الكرة الطسائرة تعد مرحلة من أصسعب مراحل تعليم اللعبـة بالنسبة للأطفال المعاقين ذهنياً في المراحل التعليمية المختلفة إضـافة إلي افتقار عناصر المنافسة خلال فترة التعليم وأيضاً الأخطاء المصاحبة للأداء المهارى حيث لا يمكن أن نتصور أن الطفل يمكن أن يؤدي المهارة بالطريقة الفنية المتلي الخالية من الأخطاء بل علي العكس من ذلك فالتوقع الطبيعي أنه عند تعلمه مهارة معينة يكون أداؤه بها كثير من الأخطاء، وهنا يكون واجب المعلم معرفة مواطن الخطأ في بلهي

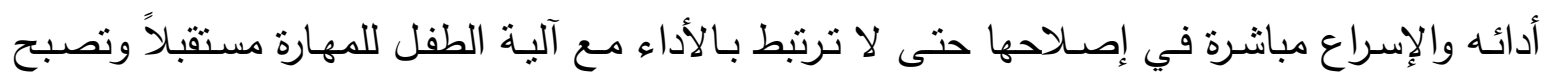

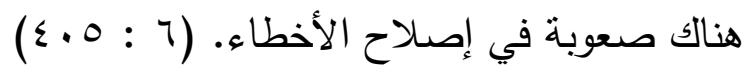
وبالإطلاع علي منهاج التربية الرياضية بصفة عامة ومنهاج الكرة الطائرة بصفة خاصـة المقرر

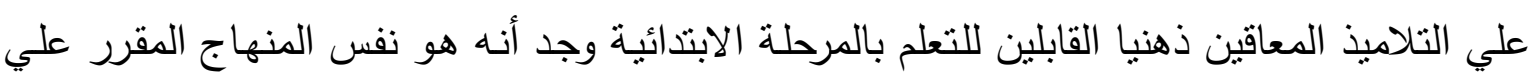
الأطفال الأسوياء لتلك المرحلة، وذلك نظراً لعدم وجود برامج تعليمية خاصـة مستخدمة الاتجاهات الحديثة في طرق التدريس، تتمي جوانب التلميذ المتعددة، الأمر الذى يؤثر سلبياً علي ناتج العملية التعليمية لهؤلاء الفئة من الأطفال المعاقين ذهنيا القابلين للتعلم. وفي ضوء ما سبق وبعد الإطلاع علي العديد من المراجع والبحوث والدراسات العلمية وفي حدود علم الباحث تبين أن فئة المعاقين ذهنيا القابلين للتعلم بالمرحلة الابتدائية لم تحظي باهتمام واضتح من

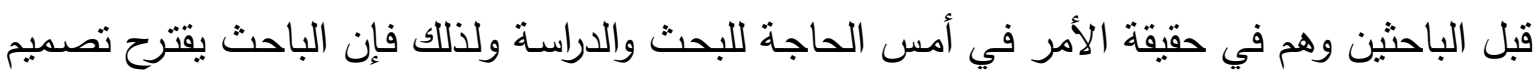
برنامج إرشادى على بعض المتغيرات البدنية والمهارية فى الكرة الطائرة ومعرفة أثره فى خفض حدة حدة السلوك العدوانى.

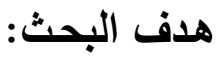

يهدف هذا البحث إلى تصميم برنامج إرشادى ومعرفة تأثيره على:

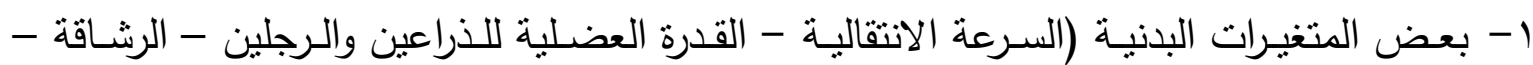

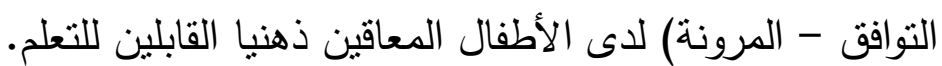
ץ- بعض مهارات الكرة الطائرة (التمرير من أعلي ولأمام - التمرير من أسفل بالساعدين - الإرسال الأمامي المواجه من أسفل) لدى الأطفال المعاقين ذهنيا القابلين للتعلم.

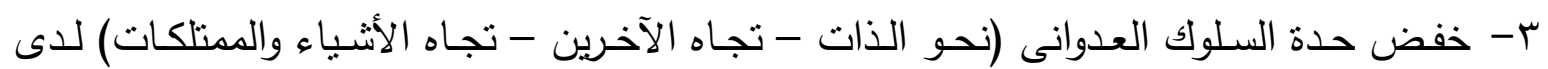
الأطفال المعاقين ذهنيا القابلين للتعلم. فروض البحث: ا - توجد فروق ذات دلالة إحصائية بين القياسات القبلية والبعدية للمجموعتين التجريبية والضابطة فى بعض المتغيرات البدنية قيد البحث لصالح القياسات البعدية. ץ- توجد فروق ذات دلالة إحصائية بين القياسات القبلية والبعدية للمجموعتين التجربيية والضابطة فى لئي بعض مهارات الكرة الطائرة قيد البحث لصالح القياسات البن لبعدية.

مجلة بحوث التربية الثاملة ـ كلية التربية الرياضية للبناتـ جامعة الزقازيق ـ المجلد الثاني- للنصف الأول للأبحاث العلميةـ 1 ا ـ بم 
- rA -

تأثئير برنامج إرشادى على بعض المتغيرات البذنية و المهارية في الكرة الطائرة وخفض حدة السلوك العدوانى لاى الأطفال المعاقين ذهنيا القابلين للتعلم r- توجد فروق ذات دلالة إحصائية بين القياسات القبلية والبعدية للمجموعتين التجريبية والضابطة فى خفض حدة السلوك العدوانى لصالح القياسات البعدية. ع - توجد فروق ذات دلالة إحصائية بين القياسات البعدية للمجموعتين التجريبية والضابطة فى بعض المتغيـرات البدنيـة ومهـارات الكـرة الطـائرة وخفض حـدة السـلوك العـدوانى قيـد البحـث لصـالح المجموعة التجريبية. ه- توجد فروق ذات دلالـة إحصـائية في معدل التغير لنسـب التحسـن بـين المجموعتين التجريبيـة والضـابطة فى بعض المتغيرات البدنية ومهارات الكرة الطائرة وخفض حدة السلوك العدوانى قيد البحث لصالح المجموعة التجريبية. مصطاح البحث: السلوك العدوانى

"هو السلوك الذى يؤدى إلى إلحاق الأذى والدمار بالآخرين بالفعل أو الكلام والجانب السلبى منه

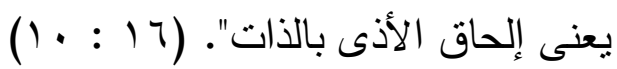

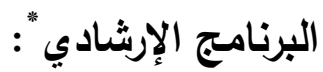

"برنامج مخطط منظم في ضوء أسس علمية لتقديم الخدمات الإرشادية في صورة جمل إرشادية داخل دروس التربية الرياضية ".

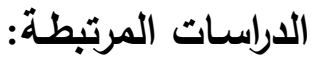

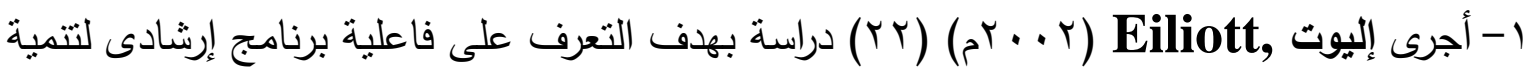

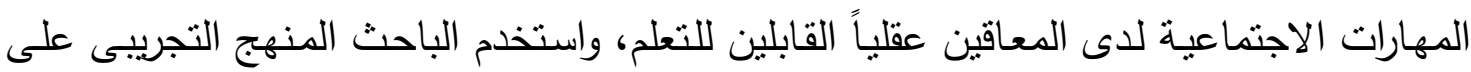
عينة قوامها (1) معاق ومعاقة من الأطفال القابلين للتعلم، ومن أدوات البحث استبيان المهارات الاجتماعية، نموذج معبأ من قبل المعلم يحتوى على الأنشطة التالية (مهارة الاستماع - التواصل البصرى - فهم لغة الجسد - توطيد الذات)، ومن أهم النتائج أن تقييم المعلم البعدي أظهر أن أفراد

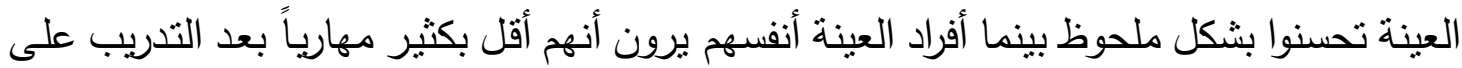

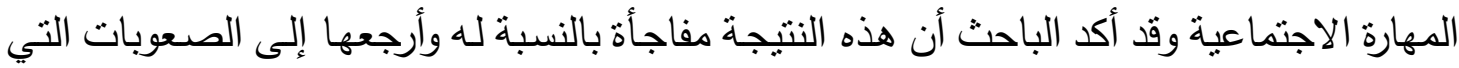
واجهت تطبيق البرنامج وكذاللك إلى صسوبات منهجية وذلك لاستخدام نموذج التقييم الذاتي لأفراد العينة ومع ذللك فإن البرنامج كان ناجحاً من خلاصل تقييم المعلمين للتلاميذ.

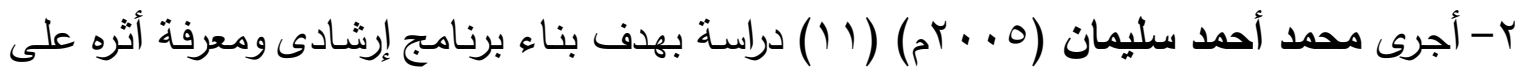
السلوك الصحي لتلاميذ المرحلة الإعدادية بمحافظة قنا، واستخدم الباحث المنهج الوصفى على ألى

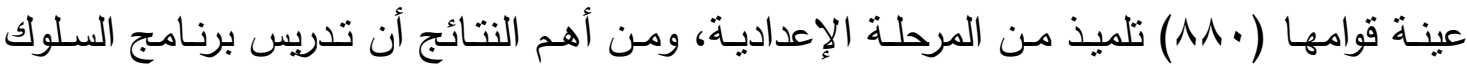
الصحى المقترح قد أدى إلى تتمية المعلومات والمعارف والمفاهيم تجاه الصحة الثخصية، التغذية التهن الصحية، الوقاية من الأمراض والحوادث، وأهمية الرياضة، صحة الى لئه البيئة.

"تعريف إجرائى

مجلة بحوث التربية الثاملة ـ كلية التربية الرياضية للبنات- جامعة الزقازيق ـ المجلد الثانيـ للنصف الأول للابحاث العلميةـ ^ ا ـ rم 
تأثثير برنامج إرشادى على بعض المتغيرات البذنية و المهارية في الكرة الطائرة وخفض حدة السلوك العدوانى لاى الأطفال المعاقين ذهنيا القابلين للتعلم ب- أجرت عايدة شعبان ونور حمودة (^ . . rم) (9) دراسـة بهدف التعرف على مدى فاعلية برنامج إرشادى فى خفض حدة السلوك العدوانى لدى الأطفال المعاقين عقليا القابلين للتعلم بمحافظة غزة، واستخدمت الباحتثان المنهج التجريبى على عينة قوامها ( • ع) طفل وطفلة من المعاقين عقليا القابلين للتعلم، بمركز شمس للرعاية اليومية، ومن أدوات البحث مقياس السلوك العدوانى ومقياس عئه الذكاء المصور، ومن أهم النتائج أن البعد الذى احتل المرتبة الأولى هو السلوك العدوانى نحو الذات والبعد الثانى و البعد الذى احتل المرتبة الثانية هو السلوك العدوانى تجاه الآخرين والبعد الذى احتل المرتبـة الثالثة هو السـلوك العدوانى تجـاه الأثـياء والممتلكات، كمـا توصلت الدراسـة أيضـاً إلى وجود فروق ذات دلالة إحصائية عند مستوى معنوية 0 . . . بين متوسطات درجات المجموعة التجريبية والمجموعة الضابطة فى القياس التتبعى والبعدى لصالح المجموعة التجربيية، وجود أثز كبير للبرنامج المقترح فى خفض حدة السلوك العدوانى لدى المجموعة التجريبية.

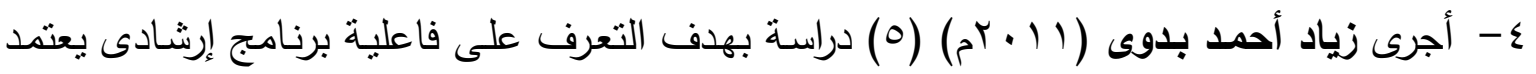
على فن القصة فى خفض السلوك العدوانى لدى المعاقين عقلياً القابلين للتعلم، واستخدم الباحث المنهج التجريبى على عينـة قوامها (7 ( ) طالباً وطالبة من المعاقين عقلياً القابلين للتعلم، ومن أدوات البحث استبيان السلوك العدوانى - البرنامج الإرشادى، وقد أسفرت النتائج على أن البرنامج الارشـادى المقترح باسـتخدام القصـة سـاهم فى خفض السـلوك العدوانى لدى المجموعتين الذكور والإناث من المعاقين عقلياً القابلين للتعلم، وجود فروق ذات دلالة إحصائية بين القياسـات القبلية والتبتعبـة والبعديـة للمجمـوعتين الذكور والإنـاث فى مسـتوى السـلوك العـدوانى لصـالح القياسـات

$$
\text { إجراءات البحثة البحثة. }
$$

اسـتخدم الباحث المـهج التجريبـى باسـتخدام التصـيم التجريبـى لمجمـوعتين أحدهما تجريبيـة الأخرى ضابطة منبعا القياسات القبلية والبعدية لمناسبته لطبيعة هذه الدراسة.

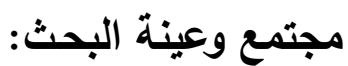

يشتمل مجتمع وعينة البحث على تناميذ الصف الخامس الابتدائى مدرسة الوحدة العربية للتربية

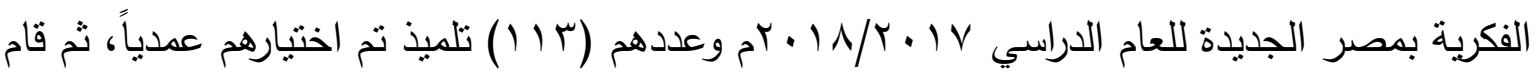

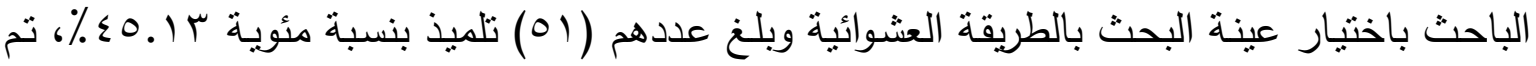

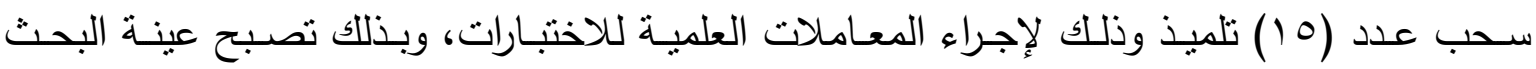
الأساسية (דr) تلميذ، تم تقسيمه إلى مجموعتين منساويتين الأولى تجريبية والثانية ضابطة قوام كل منهما (1 (1) تلميذ، بالإضافة إلى عدد (0 (1) تلميذ من المشتركين فى الأنشطة الرياضية بنفس المدرسة وفى نفس المرحلة السنية كعينة مميزة من أجل إيجاد صدق التمايز للاختبارات المستخدمة قيد البحث. 
- r. -

تأثير برنامج إرشادى على بعض المتغيرات البذنية والمهارية فحى الكرة الطائرة وخفض حدة السلوك العدوانى لاى الأطفال المعاقين ذهنيا القابلين للتعلم

أسباب اختيار العينة:

- تعتبر هذه المرحلة من أنسب المراحل السنية لنتمية قدرات الأطفال البدنية والمهارية. - تعتبر هذه المرحلة هي بداية مرحلة تعلم مهارات الكرة الطائرة حيث أنها ضمن منهج وزارة التربية والتعليم المقرر على تلاميذ الصف الخامس الابتدائى. - وفرة الأدوات والأجهزة اللازمة لتنفيذ البرنامج. ضبط متغيرات البحث:

قام الباحث بـإجراء التجانس لعينـة البحث الكلية في بعض المتغيرات التي قد يكون لها تأثير على المتغيـر التجريبـي مثنل متغيـرات النمـو (السـن - الطـول - الـوزن)، وبعض المتغيـرات البدني

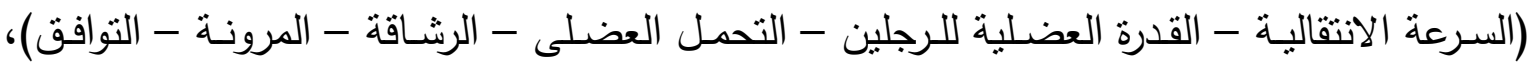
وبعض مهارات الكرة الطائرة (التمرير من أعلي وللأكسام - التمرير من أسفل بالسـاعدين - الإرسال الأمامي مواجه من أسفل)، كما يوضحه جدول (1).

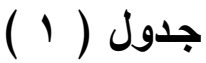

تجانس عينة البحث الأساسية والاستطلاعية في جميع المتغيرات قيد البحث

$01=0$

\begin{tabular}{|c|c|c|c|c|c|c|}
\hline الالتواء & الوسيط & الإنحريافي & المستوسطي & |القياس & المتغيـرات & \\
\hline . . & $11 . r r$ & . . $\leqslant 0 Y$ & $11 . \leqslant Y$ & سنة & السن & \\
\hline •. - & I H.... & r.079 & I TV.ro & 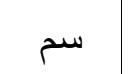 & 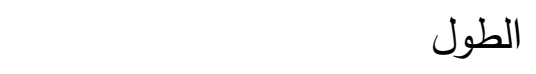 & क \\
\hline 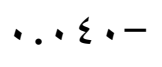 & rv.o. & 1.011 & rV.乏ᄉ & كجم & الوزن & \\
\hline $.101-$ & $\Lambda . \Sigma$. & $1.1 \leqslant r$ & A.r & ثنانية & العدو • آم من البدء العالي & \\
\hline$\cdots \wedge 1$ & $11 \% \ldots$ & V.sTr & IIr.r. & سم & الوثب العربض من الثبات & \\
\hline .099 & V... & $1 . .01$ & $V . Y_{1}$ & 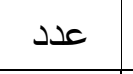 & ثنى الذراعين من الانبطاح المائل & 7 \\
\hline$\cdot . \wedge r$ & $18 \ldots$ & $1.1 \cdot \varepsilon$ & $18 . \cdot r$ & ثانية & الجرى الزجزاجى بطريقة باور & \\
\hline$\therefore 70-$ & r.o. &. $.91 \mathrm{~V}$ & $r . \Sigma \Lambda$ & سم & ثني الجذع للأمام من الوقوف & \\
\hline. .91 & $1 \cdot . r$ & $1.7 \leqslant \Lambda$ & $1 . . \%$ & ثانية & الدوائر المرقمة & \\
\hline. $.1 V T$ & 0.7 &. .177 & 0.70 & درجة & التمرير من أسفل بالساعدين & $\overline{9}$ \\
\hline$\ldots$ Vo & A.०. & $r \ldots r$ & 1.00 & درجة & التمرير من أعلي ولأمام & 7 \\
\hline$. .1 \leq \cdot-$ & V.o. & $r .1 \leq V$ & V.乏. & درجة & الإرسال الأمامي المواجه من أسفل & \\
\hline
\end{tabular}

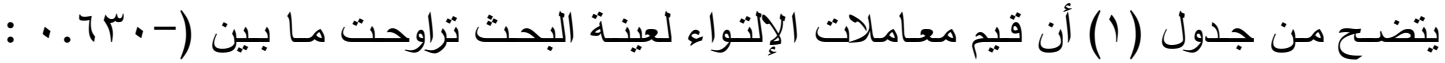

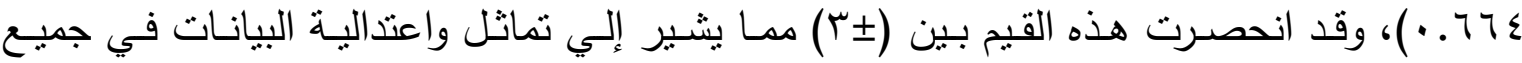
المتغيرات قيد الدراسة.

مجلة بحوث التربية الثاملة ـ كلية التربية الرياضية للبنات- جامعة الزقازيق ـ المجلد الثانيـ للنصف الأول للابحاث العلميةـ ^ 1 ـ rم 
- M -

تأثير برنامج إرشادى على بعض المتغيرات البذنية والمهارية في الكرة الطائرة وخفض حدة السلوك العدوانى لاى الأطفال المعاقين ذهنيا القابلين للتعلم أدوات ووسائل جمع البيانات - جهاز الرستاميتز Rstamitr لقياس الطول (بالسنتيمتز) والوزن بالكيلوجرام وتم معايرة هذا الجهاز قبل وخلال استخدامه. - كور ملونة - مكعبات نتس - مكعبات ملونة مختلفة الأحجام - كرات طائرة صغيرة الحجم.

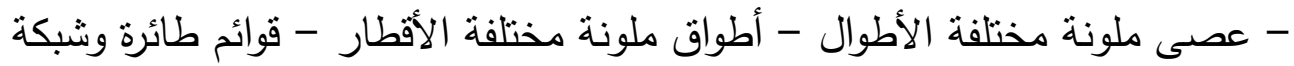
- أثنياء منتوعة مختلفة الأشكال - أوعية فارغة مختلفة الأحجام والألوان - مسطرة مدرجة. - زجاجات بلاستيكية - أكياس حبوب ورمل مختلفة الأوزان. الاختبارات المستخدمة فى البحث: 1- الاختبارات البذنية: (ملحق ب) م تحديد المتغيرات البدنية المرتبطة بمهارات الكرة الطائرة قيد البحث والاختبارات التى تقيسها من

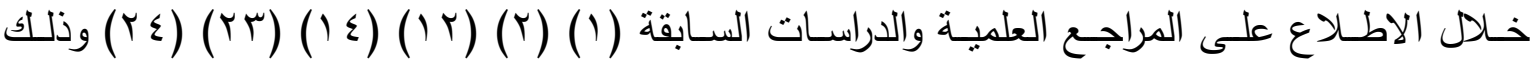
بحصر جميع المتغيرات البدنية والاختبارات الخاصـة بها ووضعها فى استمارة استطلاع رأى (ملحق 1) وتم عرضـها على السـادة الخبراء فى مجال طرق التدريس وعلم النفس الرياضـى والطب النفسى والصـحة النفسية (ملحق ب) لتحديد أهم المتغيرات البدنيـة والاختبـارات التى تقيسـها، وقد ارتضىى الباحث بنسبة ، V\% فأكثر ، وجدول ( r ) يوضح ذلك. جدول (r)

النسبة المئوية لأراء الخبراء لتحديد المتغيرات البدنية وأهم الاختبارات التى تقيسها

\begin{tabular}{|c|c|c|c|c|}
\hline النسبة المئويـة & عدد الموافِيْنَ & الاختبار ات البدنية & المتغيرات البدنية & 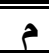 \\
\hline 7.2 & $\varepsilon$ & ـ العدو · ا ثُواني بالمسافة. & \multirow{3}{*}{ السرعة } & \multirow{3}{*}{1} \\
\hline $7.1 \cdot \cdot$ & $1 \cdot$ & ـ العدو • ب مثر من البدء العالي. & & \\
\hline صفر .7 & - & ـ العدو • ع مثر من البدء المنخفضض. & & \\
\hline 7.2 & $\xi$ & ـ الوتب العمودي من التبات. & \multirow{3}{*}{ القدرة العضلية } & \multirow{3}{*}{ r } \\
\hline$\% 1 \cdot \cdot$ & $1 \cdot$ & ـ الوثب العربض من التبات. & & \\
\hline $7.7 \cdot$ & 7 & ـ الوثب العمودى من الحركة. & & \\
\hline $7.7 \cdot$ & 7 & ـ الجلوس من الركود من وضع نتي الركبنين. & \multirow{3}{*}{ 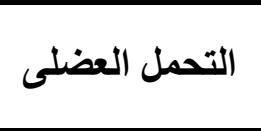 } & \multirow{3}{*}{ r } \\
\hline $7.1 \cdot \cdot$ & $1 \cdot$ & ـ ثتى الذر اعين من الانبطاح المائل. & & \\
\hline $7.1 \cdot$ & $T$ & - رمي كرة زنة . . 1 جرام لابعد مسافة. & & \\
\hline 7. & $T$ & ـ الجري المكوكي ؛ × •"م. & \multirow{3}{*}{ الرشاقة } & \multirow{3}{*}{$\varepsilon$} \\
\hline T. & T & ـ الجري الارتدادي ع×× ام. & & \\
\hline $7.1 \cdot$ & $1 \cdot$ & 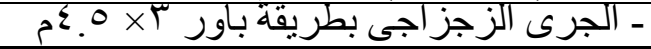 & & \\
\hline صفر.7 & - & - دوران الجذع على الجانبين. & \multirow{3}{*}{ المرونة } & \multirow{3}{*}{0} \\
\hline$\% 1 \cdot$ & $1 \cdot$ & ـ ثتي الجذع للَمام من الوقوف. & & \\
\hline T.T. & T & ـ ثني الجذع للهمام مع وضع الجلوس الطويل. & & \\
\hline T.T. & T & ـ الوقوف فلى مشط القدم. & \multirow{3}{*}{ 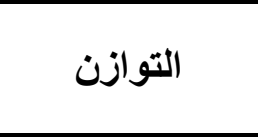 } & \multirow{3}{*}{7} \\
\hline $7.1 \cdot$ & T & ـ المشّى على عارضنة توازن لمسافة نم. & & \\
\hline \%. & Y & ـ عمل مبزان افقى. & & \\
\hline 7.0 & $\overline{0}$ & - رمي الكرات على الحائط. & \multirow{3}{*}{ التوافق } & \multirow{3}{*}{ V } \\
\hline T. & T & ـ اختبار نط الحبل. & & \\
\hline $7 \cdot \cdots$ & $1 \cdot$ & ـ الدوائر المرقفة. & & \\
\hline
\end{tabular}

مجلة بحوث التربية الثاملة ـ كلية التربية الرياضية للبنات- جامعة الزقازيق ـ المجلد الثانيـ للنصف الأول للابحاث العلميةـ ^ 1 ـ rم 
$-T^{\prime}-$

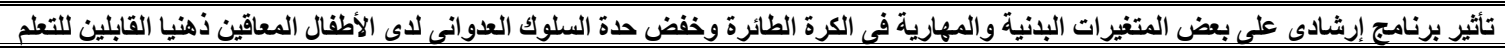

يتضح من جدول (Y) أن النسبة المئوية لآراء الخبراء فى المتغيرات البدنية المرتبطة بمهارات

الكرة الطائرة قيد البحث انحصرت ما بين (صفر \% - . . (\%)، وفى ضوء ذلك تم قبول الاختبارات

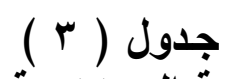

البدنية التالية، كما يوضحها جدول ( r ).

نتائج أهم الاختبارات البدنية المستخدمة طبقا لرأى السادة الخبراء

\begin{tabular}{|c|c|c|}
\hline وحدة القياس & الاختبارات البدنية المرشحة & المتغيرات البدنية \\
\hline ثانية & - العدو • ب منز من البدء العالي. & السرعة الانتقالية \\
\hline 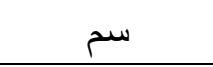 & - الوثب العريض من الثبات & القدرة العضلية للرجلين \\
\hline عدد & - ثنى الذراعين من الانبطاح المائل. & التحمل العضلى \\
\hline ثانية & - الجرى الزجزاجى بطريقة باور س× ه.عم & الرشاقة \\
\hline 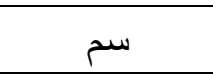 & - ثني الجذع للأكام من الوقوف & المرونة \\
\hline ثانية & - الدوائر المرقمة & 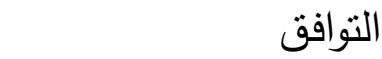 \\
\hline
\end{tabular}

يتضح من جدول ( r ) نتائج أهم المتغيرات البدنية والاختبارات التى تقيسها بناء على رأى

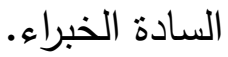

r - الاختبارات مهارات الكرة الطائرة (ملحق ع ع )

تم اختيار مهارات الكرة الطائرة المقررة على تلاميذ الصف الخامس الابتدائى طبقا لمنهج دليل المعلم والذى يتتاسب مع المرحلة السنية قيد البحث ووضع لها اختبارات مهارية وعرضها على السادة

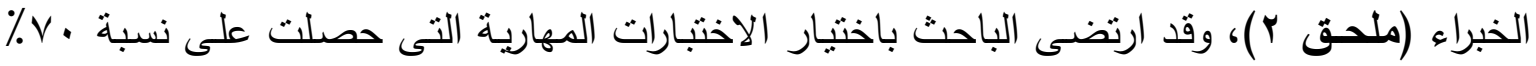

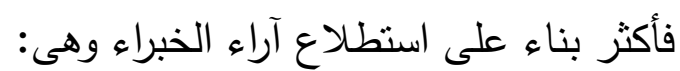

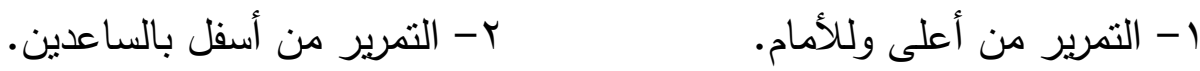
r- الإرسال الأمامي المواجه من أسفل.

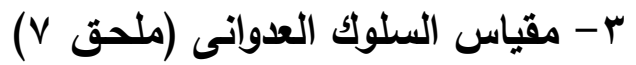
قـام الباحثث بـاجراء شـامل للمراجـع والدراسـات النظريـة العربيـة والأجنبيـة التـي تتاولت هـا الموضوع، كما تم إجراء مقابلات مـع أعضـاء هيئة التدريس بالجامعات فى مجال علم النفس للتعرف على أبعاد مقياس السلوك العدوانى لدى الأطفال المعاقين ذهنيا القابلين للتعلم حيث حدد ثناءث أبعاد لقياس السلوك العدوانى وهما:

1 - البعد الأول: السلوك العدوانى نحو الذات ويتضمن ( • ب) عبارة.

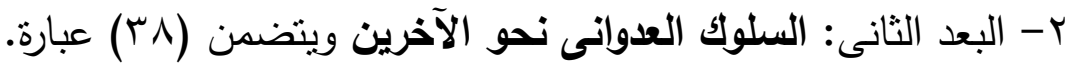

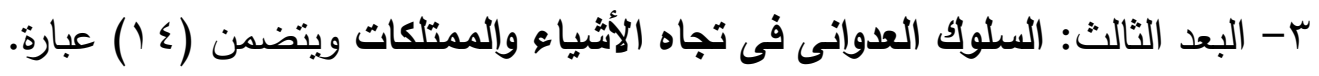
تم عرض أبعاد السلوك العدوانى ومجموعة من العبارات لكل بعد فى صورته الأولية (ملحق •) على عدد (• () من السادة الخبراء فى مجال طرق التدريس وعلم النفس الرياضسى والطب النفسى 
$-r+$

تأثير برنامج إرشادى على بعض المتغيرات البلنية والمهارية في الكرة الطائرة وخفض حدة السلوك العدو انى لاى الأطفال المعاقين ذهنيا القابلين للتعلم والصحة النفسية (ملحق r)، وذلك لتحديد النسبة المئويـة لكل عبارة تتدرج تحت هذا البعد، ويوضـح جدول ( ع ) النسبة المئوية لاتفاق الخبراء فى تحديد عبارات الأبعاد.

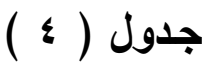

النسبة المئوية لاتفاق الخبراء حول تحديد أبعاد وعبارات مقياس السلوك العدوانى $1 \cdot=\dot{0}$

\begin{tabular}{|c|c|c|c|c|c|c|c|c|c|c|c|c|c|}
\hline المئوية & r & المئوية & r & المئوية & r & المئوية & r & المئوينة & r & المئوية النسبة & $\hat{r}$ & المئوية & r \\
\hline \multicolumn{14}{|c|}{ البعد الأول: السلوك العدوانى نحو الذات: } \\
\hline$\% 1 \ldots$ & 19 & $\% \wedge$ & 17 & $\%$ & ir & $\% 1 \ldots$ & 1 . & $\%$ & V & $\% 1 \ldots$ & $\varepsilon$ & $\% 1 \ldots$ & 1 \\
\hline \multirow[t]{2}{*}{$\% 9$. } & $r$. & $\% 1 \ldots$ & iv & $\% 1 \ldots$ & $1 \varepsilon$ & $\%$ \%. & 11 & $\% \wedge$. & $\Lambda$ & $\% \vee$ & 0 & $\% 9$. & $r$ \\
\hline & & $\% 1 \ldots$ & 11 & $\% 9$. & 10 & $\% 9$. & ir & $\%$ & 9 & $\% 1 \ldots$ & 7 & $\% 1 \ldots$ & $r$ \\
\hline \multicolumn{14}{|c|}{ البعد الثانى: السلوك العدوانى نحو الآخرين: } \\
\hline$\% 1 \ldots$ & re & $\% 1 \ldots$ & r) & $\% 1 \ldots$ & ro & $\% 1 \ldots$ & 19 & $\%$ \%. & $1 r$ & $\%$ \%. & $V$ & $\% \wedge$. & 1 \\
\hline \multirow[t]{5}{*}{$\%$. } & rA & $\% \vee$ & Tr & $\% 9$. & $r T$ & $\% 0$. & $r$. & $\% 9$. & $1 \varepsilon$ & $\% 1 \ldots$ & $\Lambda$ & $\% 1 \ldots$ & $r$ \\
\hline & & $\% 1 \ldots$ & س & $\% 1 \ldots$ & YV & $\% 1 \ldots$ & $Y_{1}$ & $\% 1 \ldots$ & 10 & $\% \vee$ & 9 & $\% \vee$ & r \\
\hline & & $\% 1 \ldots$ & $r \varepsilon$ & $\% 9$. & $r \wedge$ & $\% 1 \ldots$ & rr & $\% 1 \ldots$ & 17 & $\% 1 \ldots$ & 1. & $\% 1 \ldots$ & $\varepsilon$ \\
\hline & & $\%$ r. & ro & $\% 1 \ldots$ & $r q$ & $\% v$. & rr & $\% 1$. & $1 \mathrm{~V}$ & $\% 1 \ldots$ & 11 & $\% 9$. & 0 \\
\hline & & $\%$ & r & $\% 1 \ldots$ & r. & $\% 9$. & $r \varepsilon$ & $\% 1 \ldots$ & 11 & $\% 1 \ldots$ & it & $\% 1 \ldots$ & 7 \\
\hline \multicolumn{14}{|c|}{ البعد الثالث: السلوك العدوانى فى تجاه الأشياء والممتلكات: } \\
\hline$\% 1$ & 14 & $\%$ & 11 & $\% 1 \ldots$ & 9 & $\% 1 \ldots$ & V & $\% 1 \ldots$ & 0 & $\% 1 \ldots$ & $r$ & $\% 1 \ldots$ & 1 \\
\hline$\% 1 \cdots$ & $1 \varepsilon$ & $\% 1 \ldots$ & 14 & $\% 1 \ldots$ & 1. & $\% 1 \cdots$ & $\Lambda$ & $\% 9$ & 7 & $\% 9$. & $\varepsilon$ & $\% 1 \ldots$ & r \\
\hline
\end{tabular}

يتضـح من جدول ( ع ) أن نسبة أراء الخبراء قد أشـارت إلى قبول بعض العبارات المقترحة

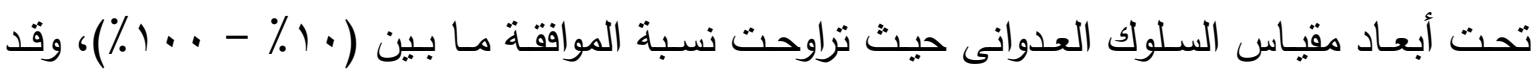
ارتضى الباحث بالعبارات التي حصلت على نسبة • ٪\% فأكثر وفقاً لرأى السادة الخبراء وجدول ( 0 ) يوضح العبارات المحذوفة من كل بعد.

\section{جدول (•)}

عدد العبارات المحذوفة وأرقامها من مقياس السلوك العدوانى وفقا لنسبة أراء السادة الخبراء

\begin{tabular}{|c|c|c|c|c|}
\hline بعد ألحذف & ارقام العبّارِّات & محذبوفة & العباراتي & الأبعـاد \\
\hline T. & - & - & T. & الاول: السلوك العدو انى نحو الذات \\
\hline M & 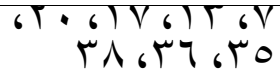 & V & rᄉ & الثانى: السلوك العدوانى نحو الآخرين \\
\hline $1 \leqslant$ & - & - & $1 \leq$ & التّالث: السلوك العدو انى فى تجاه الآشياء و الممتلكات \\
\hline 70 & & $\bar{V}$ & VY & العدد الكلى للاعبارات \\
\hline
\end{tabular}

مجلة بحوث التربية الثاملة ـ كلية التربية الرياضية للبناتـ جامعة الزقازيق ـ المجلا الثانيـ للنصف الأول للأبحاث العلميةـ ^I ـ بم 
$-r \varepsilon-$

تأثير برنامج إرشادى على بعض المتنيرات البنية والمهارية في الكرة الطائرة وخفض حدة السلوك العدو انى لاى الأطفال المعاقين ذهنيا القّبلين للتعلم يتضح من جدول ( 0 ) إجمالى العدد الكلى للعبارات بعد حذف العبارات التى حصلت على

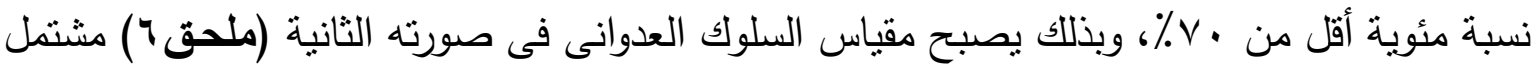

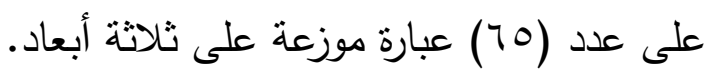

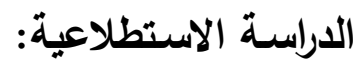

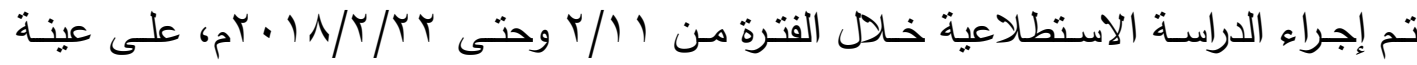
قوامها (0 1) طفل من مجتمع البحث وخارج العينة الأساسية، واستهدفت هذه المرحلة التأكد من: - سلامة المكان والأدوات المستخدمة وما يتعلق بها من إجراءات القياس. - اكتشاف الصعوبات التى يمكن مواجهتها أثتاء إجراءات البحث لتنافى حدوثها. - التعرف على الوقت الذى تستخرقه القياسات، والجهد المبذول فى الإعداد والتتظيم والإدارة والتشجيل. - إيجاد المعاملات العلمية للاختبارات المستخدمة فى البحث. أولاً: حساب المعاملات العلمية للاختبارات البدنية:

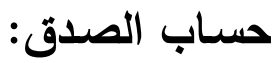

تم حساب صدق المتغيرات البدنية قيد البحث عن طريق تطبيق الاختبارات على مجموعتين متساويتين من الأطفال، قوام كل منهما (0 (1) طفل، المجموعة الأولى هم العينة الاستطلاعية (غير لئرئ مميزة)، والمجموعة الثانية هم الأطفال الممارسون الأنشطة الرياضية بالمدرسة (مميزة)، وذلك خلال

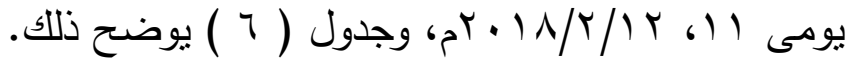 جدول ( 1 ( )}

دلالة الفروق بين المجموعتين المميزة وغير المميزة فى المتغيرات البدنية قيد البحث $10=r_{r}=1 \dot{0}$

\begin{tabular}{|c|c|c|c|c|c|c|}
\hline \multirow{2}{*}{ قيمة "تمس } & \multicolumn{2}{|c|}{ غير المميزة } & \multicolumn{2}{|c|}{ المجموعة المميزة } & \multirow{2}{*}{ وحدة } & \multirow{2}{*}{ 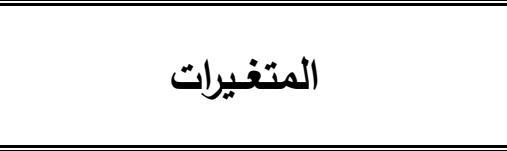 } \\
\hline & ${ }^{\prime} \varepsilon \pm$ & ${ }^{\prime} \varepsilon \pm$ & سَنَ & سََ & & \\
\hline$* q .+r q$ & $1.1 \leq \varepsilon$ & A.rV & ..Mร & $v \ldots$ & ثانية & العدو • بم من البدء العالي \\
\hline$* \varepsilon . \Gamma 19$ & $V . \Sigma Y$. & $11 \% .1$. & $\varepsilon .101$ & $1 Y \cdot .1 Y$ & سم & الوثب العريض من الثبات \\
\hline$* \wedge . .09$ &.$\wedge r t$ & $V .10$ & .940 & 9.0 & 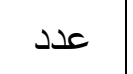 & ثنى الذراعين من الانبطاح المائل \\
\hline$* 11 . \wedge \vee 0$ & 1.110 & IV.IT &. $.79 V$ & $1 \leqslant .10$ & ثانية & الجرى الزجزاجى بطريقة باور \\
\hline$* \vee . \wedge \neg$. & .911 & $r . \Sigma r$ & $1.1 \leq r$ & $\varepsilon .7$. & سم - & ثني الجذع من الوقوف \\
\hline$* 0.0 \leqslant V$ & $1 . t \leq r$ & 1.r. & $.7 \leq V$ & $\Lambda . \leqslant 0$ & ثنانية & الدوائر المرقمة \\
\hline
\end{tabular}

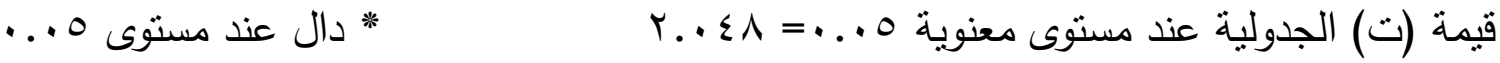
يتضـح من جدول ( 7 ) وجود فروق دلالة إحصائية بين المجموعتين المميزة وغير المميزة

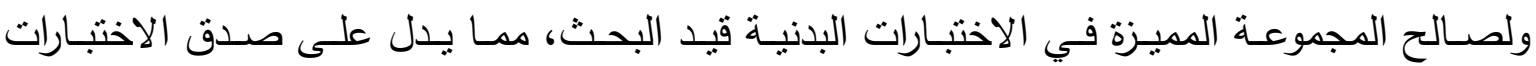
المستخدمة في قياس ما وضعت من أجله لقدرتها على التمبيز بين المجموعتين. 


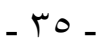

تأثير برنامج إرشادى على بعض المتغير ات البذنية و المهارية في الكرة الطائرة وخفض حدة السلوك العدوانى لاى الأطفال المعاقين ذهنيا القابلين للتعلم

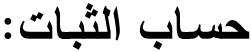

تم إيجـاد معامل ثبـات المتغيرات البدنيـة قيد البحث، مـن خـلال تطبيـق الاختبـار ثم إعـادة التطبيـق Test-Retest بفاصـل زمنـي قـدره (ب) أيـام بـين التطبيقين، وذلـك على عينــة البحـث

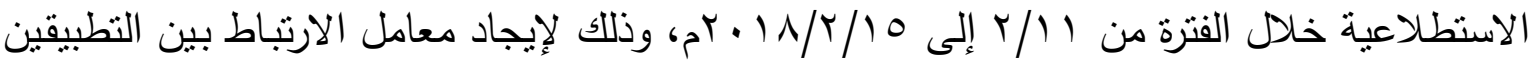
باستخدام معامل الارتباط البسيط (بيرسون)، وجدول (V) يوضح ذلإن.

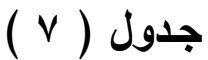

معامل الثبات بين التطبيقين فى المتغيرات البدنية قيد البحث

$10=\dot{0}$

\begin{tabular}{|c|c|c|c|c|c|c|}
\hline \multirow{2}{*}{ الارثباط معامل } & \multicolumn{2}{|c|}{ التطبيق الثّانح } & \multicolumn{2}{|c|}{ التطبيق الاول } & \multirow{2}{*}{ |القياس } & \multirow{2}{*}{ المتغيرات } \\
\hline & $\varepsilon \pm$ & سنr & $\varepsilon \pm$ & سَر & & \\
\hline$* . V I r$ & $1.1 \% 0$ & $\overline{\Lambda . M}$ & $1.1 \leqslant \varepsilon$ & $\lambda . \mu V$ & ثانية & • •ام من البدء العالي \\
\hline$* . .179$ & V.乏Tr & IIT.Y. & V.乏Y. & 111.1. & سم & الوثب العريض من الثبات \\
\hline$* . \wedge \Gamma$ & $\cdot .9 \cdot r$ & V.r. & $\therefore$. $Y Y T$ & 8.10 & عدد & ثنى الذر اعين من الانبطاح المائل \\
\hline$* . \wedge \cdot 7$ & 1.117 & IV.r & 1.110 & IV.IT & ثانية & الجرى الزجز اجى بطريقة باور \\
\hline$* . \wedge \leqslant 7$ & .910 & Y. $\Sigma \Lambda$ & .911 & $r . \Sigma T$ & سم & الجذع من الوقوف \\
\hline *. .Vr & $1.70 \mathrm{~V}$ & $1 \cdot . \varepsilon \cdot$ & $1.7 \leqslant Y$ & $1 \cdot r \cdot$ & تَانياًة & الدوائر المرقمة \\
\hline
\end{tabular}

يتضـح من جدول ( V ) وجود علاقة ارتباطيـة دالة إحصـائياً بين التطبيقين الأول والثانى

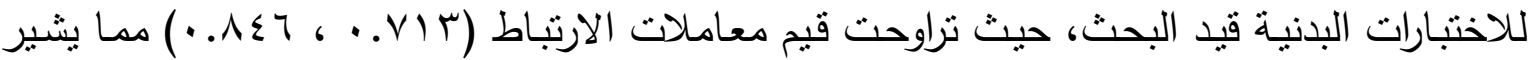
إلى ثبات ثللك الاختبارات. ثالثاً: حساب المعاملات العلمية لاختبارات مهارات الكرة الطائرة:

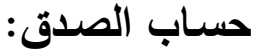

تم حساب صدق اختبارات مهارات الكرة الطائرة عن طريق تطبيق الاختبارات على مجموعتين متساويتين من الأطفال، قوام كل منهما (10) طفل، المجموعة الأولى هم العينة الاستطلاعية (غير مميزة)، والمجموعة الثانية هم الأطفال الممارسون الأنشطة الرياضية بالمدرسة (مميزة)، وذلك خلال

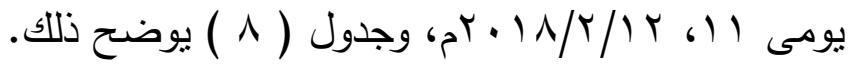

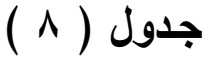

دلالة الفروق بين المجموعتين المميزة وغير المميزة فى مهارات الكرة الطائرة قيد البحث

$10=r \dot{r}=10$

\begin{tabular}{|c|c|c|c|c|c|c|}
\hline \multirow{2}{*}{ "قامحسو "تبة } & \multicolumn{2}{|c|}{ غيز المميزة } & \multicolumn{2}{|c|}{ المجمو عة المميزة } & \multirow{2}{*}{ |القياس } & \multirow{2}{*}{ المتغـيرات } \\
\hline & $\varepsilon \pm$ & $\varepsilon \pm$ & سَّ & سنَ & & \\
\hline$* T . V T V$ & $1 . V \Gamma \wedge$ & $7 . Y \leqslant$ & $1 . \wedge$. & A.r. & درجة & التمرير من أسفل بالساعدين \\
\hline$* 0 . r \varepsilon$ & .970 & 0.1. & $\because \Lambda V Y$ & 7.10 & | درجة & التمرير من أعلي وللأمام \\
\hline$* \Gamma \cdot T \cdot T$ & $1.71 \%$ & $0 . r_{0}$ & $1 . \Sigma Y Y$ & $\mathrm{~V} .10$ & | درجة & الإرسال الأمامي المو اجه من أسفل \\
\hline
\end{tabular}

مجلة بحوث التربية الثاملة ـ كلية التربية الرياضية للبنات- جامعة الزقازيق ـ المجلد الثانيـ للنصف الأول للأبحاث العلميةـ ^1 ـ بم 
-4 -

تأثير برنامج إششادى على بعض المتغيرات البلنية والمهارية في الكرة الطائرة وخفض حدة السلوك العدوانى لاى الأطفال المعاقين ذهنيا القابلين للتعلم يتضح من جدول (^) وجود فروق دالة إحصائية بين المجموعتين المميزة وغير المميزة ولصـالح المجموعة المميزة في اختبارات مهارات الكرة الطائرة قيد البحث، ممـا يدل على صدق الاختبارات المستخدمة في قياس ما وضعت من أجله لقدرتها على التمييز بين المجموعتين. حساب الثبات:

تم إيجاد معامل ثبات اختبارات مهارات الكرة الطائرة قيد البحث، من خلال تطبيق الاختبار ثم إعادة التطبيق Test-Retest بفاصل زمني قدره (r) أيسام بين التطبيقين، وذلك على عينـة البحث

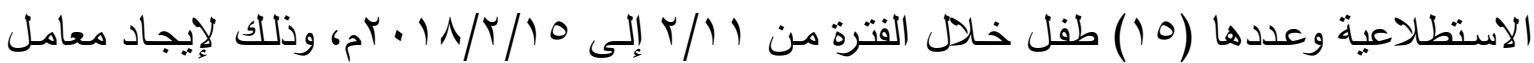
الارتباط بين التطبيقين، وجدول (9) يوضح ذلك.

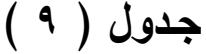

معامل الثبات بين التطبيقين في مهارات الكرة الطائرة قيا البحث

\begin{tabular}{|c|c|c|c|c|c|c|}
\hline \multirow{2}{*}{ معامل } & \multicolumn{2}{|c|}{ التطبيق الثانى } & \multicolumn{2}{|c|}{ التطبيق الاول } & \multirow{2}{*}{ وحدة } & \multirow{2}{*}{ المتغيرات } \\
\hline & $\varepsilon \pm$ & سَنr & $\varepsilon \pm$ & سََ & & \\
\hline$* . .799$ & $1 . V \leq r$ & 7.r. & $1 . V T \wedge$ & $7 . r \leq$ & | - درجة & التمرير من أسفل بالساعدين \\
\hline$* . \mathrm{VIV}$ & $.9 \leq \pi$ & 0.10 & .970 & 0.1 & | درجة & التمرير من أعلي ولأكام \\
\hline$* . \vee Y \leq$ & 1.747 & 0. & $1.71 \%$ & 0. Yo & | درجة & الإرسال الأمامي المواجه من أسفل \\
\hline
\end{tabular}

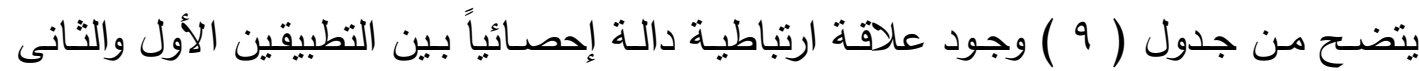

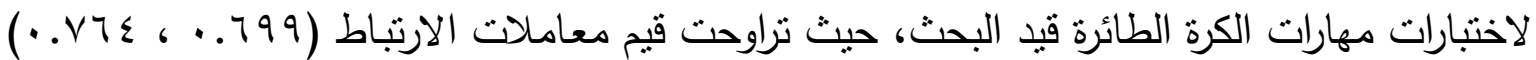
مما يشير إلى ثبات ثلك الاختبارات. المعاملات العلمية لمقياس السلوك العدوانى: أولاً: حساب صدق الاتساق الاخلى

تم حسـاب الصـدق على أفراد العينـة الاستطلاعية وعددهم (0 (10) طفل من مجتمـع البحث وخارج العينة الأساسية عن طريق صدق الاتسـاق الداخلى، وذلك بحسـاب معامل الارتباط بين كل

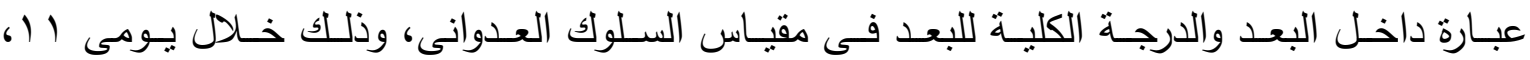

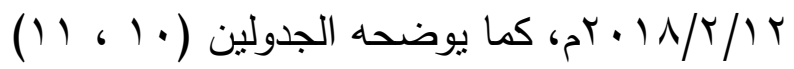


$-r R_{-}$

تأثير برنامج إرشادى على بعض المتفيرات البذنية والمهارية في الكرة الطائرة وخفض حدة السلوك العدوانى لاى الأطفال المعاقين ذهنيا القابلين للتعلم

$$
\text { جدول (1.) }
$$

صدق الاتساق الاخلى لأبعاد وعبارات مقياس السلوك العدوانى

$10=\dot{0}$

\begin{tabular}{|c|c|c|c|c|c|c|c|c|c|c|c|}
\hline الارتباط & م & الارتباط & r & الارتباط & م & الارتباط & م & الارتباط & r & الارتباط & p \\
\hline & & & & & & \multicolumn{6}{|c|}{ البعد الأول: السلوك العدوانى نحو الأات: } \\
\hline & & $* .7 \leqslant r$ & $1 V$ & $* .07 V$ & r & $* .711$ & 9 & *..orl & 0 & $* .071$ & 1 \\
\hline & & $* .0 \wedge r$ & 11 & $* .0 \leqslant 1$ & $1 \varepsilon$ & $* .0 \leqslant 9$ & 1. & *.or & 7 & $* .0 V 1$ & $r$ \\
\hline & & $* . .7 Y_{1}$ & 19 & *. . & 10 & *. & 11 & $* .7 \leq \varepsilon$ & V & $* .07 r$ & r \\
\hline & & *.orr & r. & $* . .7 \cdot r$ & 17 & $* .0 \leqslant 0$ & 14 & $* .01$. & $\Lambda$ & *. . OVT & $\varepsilon$ \\
\hline
\end{tabular}

تابع جدول (1. (1)

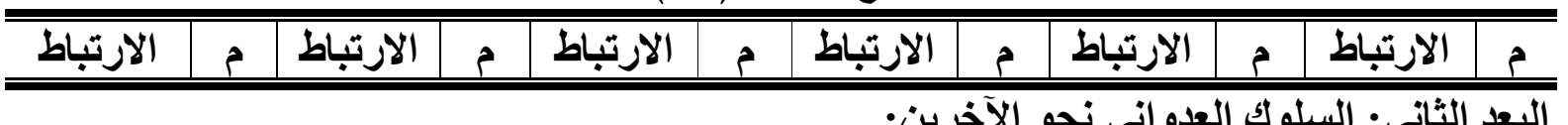
البعد الثاني: السلوك العدوانى نحو الآخرين:

\begin{tabular}{|c|c|c|c|c|c|c|c|c|c|c|c|}
\hline$* .77$. & T & $* .000$ & To & $* .07 r$ & 19 & $* .7 V I$ & $1 T$ & $* .0 \wedge \mu$ & $V$ & $* .7 Y 0$ & 1 \\
\hline & & $.0 Y Y$ & rq & $* .0 \leqslant 7$ & Y. & *. IYV & $1 \varepsilon$ & $* .71$ & $\Lambda$ & $* .0 \wedge 7$ & r \\
\hline & & $* .09$. & TV & $* .7 \leqslant$. & YI & *. . & 10 & $*$ & 9 & $* .071$ & T \\
\hline & & $* .0 \% 9$ & rᄉ & $* .09 \varepsilon$ & rY & $* .0 \leqslant \wedge$ & 17 & $*$ & $1 \cdot$ & $*$ *. or & $\varepsilon$ \\
\hline & & $* .017$ & pq & $* . .0 V T$ & tr & $* .0 \wedge 7$ & 18 & $* .07 r$ & 11 & *. OY & 0 \\
\hline & & $* .70$ & $r$ & $* .071$ & YE & $* .7$. & 11 & $* .71 V$ & Ir & $* .07 \varepsilon$ & 7 \\
\hline
\end{tabular}

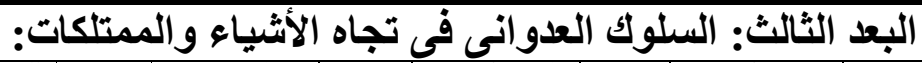

\begin{tabular}{|c|c|c|c|c|c|c|c|c|c|c|c|}
\hline & & $* .711$ & $1 T$ & $* . .7 . r$ & $1 \cdot$ & $*$ *.人। & V & $* .719$ & $\varepsilon$ & $* .7 V V$ & 1 \\
\hline & & $* .09 r$ & $1 \varepsilon$ & $* .077$ & 11 & $* .0 \leqslant T$ & $\Lambda$ & $* .71 \varepsilon$ & 0 & $* .7 Y Y$ & r \\
\hline & & & & $* .019$ & IT & $* .70$. & 9 & *. OVY & 7 & $* .099$ & T \\
\hline
\end{tabular}

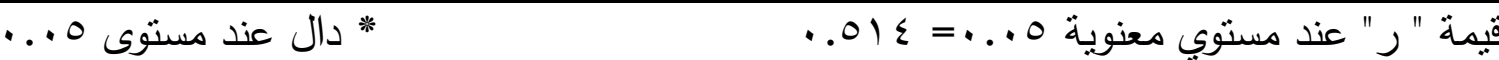

يتضـح مسن جـول ( • 1) أن معـاملات الارتبـاط بـين كل عبـارة والدرجـة الكلبـة للبعد دالـة

إحصائيا عند مستوى 0 . . •، مدا يدل على صدق مقياس السلوك العدوانى فيما وضع من أجله.

\section{جدول (11)}

معامل الارتباط بين أبعاد مقياس السلوك العدوانى والدرجة الكلية للمقياس

$10=\dot{0}$

\begin{tabular}{|c|c|c|c|}
\hline معامل الارتباط & وحدة القياس & الأبعـاد & \\
\hline$* . . V \leq r$ & درجة & السلوك العدو انى نحو الذات & \\
\hline$* .70 r$ & درجة & السلوك العدو انى نحو الآخرين & \\
\hline *.VYY & درجة & السلوك العدو انى فى تجاه الأشياء و الممتلكات & \\
\hline$* . V Y \Lambda$ & درجة & المقياس ككل & \\
\hline
\end{tabular}

مجلة بحوث التربية الثاملة ـ كلية التربية الرياضية للبنات- جامعة الزقازيق ـ المجلد الثانيـ للنصف الأول للأبحاث العلميةـ ^ ا ـ بم 
-

تأثير برنامج إرشادى على بعض المتغيرات البذنية والمهارية في الكرة الطائرةٌ وخفض حدة السلوك العدوانى لاى الأطفال المعاقين ذهنيا القابلين للتعلم

يتضـح من جدول (11) أن معاملات الارتباط بين كل محور والدرجة الكليـة للمقياس دالة

إحصائيا عند مستوى 0 . ..، وهذا يدل على أن الأبعاد مرتبطة بمقياس السلوك العدوانى ككل. ثانياً: حساب الثبات:

قام الباحث بإجراء الثبات لمقياس السلوك العدوانى وأبعاده المختلفة على نفس عينة الدراسـة الاستطلاعية السابقة باستخدام طريقة تطبيق الاختبار ثم إعادة تطبيقه Test - Retest تحت نفس

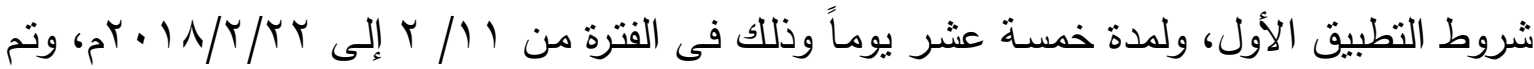
حساب معامل الارتباط بين التطبيقين، كما هو موضح بجدول (Y)

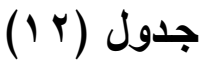

معامل الثبات لمقياس السلوك العدواني وأبعاده المختلفة

\begin{tabular}{|c|c|c|c|c|c|c|c|}
\hline \multirow{2}{*}{ الارثباط معامل } & \multicolumn{2}{|c|}{ التطبيت الثانى } & \multicolumn{2}{|c|}{ التطبيق الأول } & \multirow{2}{*}{ |القياس } & \multirow{2}{*}{\multicolumn{2}{|c|}{ الأبعـاد }} \\
\hline & $\varepsilon \pm$ & سَّ & $\varepsilon \pm$ & سَر & & & \\
\hline$* .719$ & 1.MT & ro.r. & $1 . \Sigma \cdot r$ & $r 0.10$ & درجة & السلوك العدو انى نحو الذات & \\
\hline$* . . \mathrm{N}$ & $1.1 \leqslant 9$ & $\varepsilon r .7$. & $1.10 \mathrm{~V}$ & $\varepsilon r .0$. & درجة & السلوك العدوانى نحو الآخرين & . \\
\hline$* . .7 \vee \wedge$ &.$\vee V 71$ & r.so &.$\vee \vee \varepsilon$ & rY.A. & درجة & و السمتلكات العدو انى فى تجاه الاشياء & 7 \\
\hline$* . \wedge I r$ & $5.1 \%$ & rᄉ०.r. & $\varepsilon$. TOV & 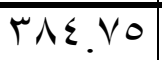 & درجة & المقياس ككل & \\
\hline
\end{tabular}

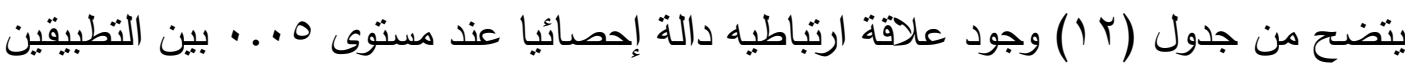

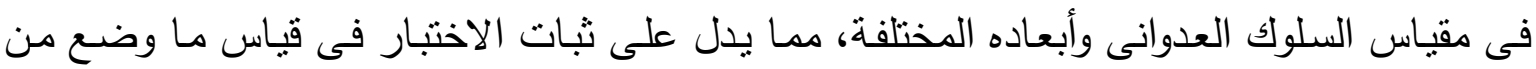
أجله.

كما تم حسـاب معامل ثبات الاستبيان على أفراد العينـة الاستطلاعية السـابقة وذلك بتطبيق معامل ألفا كرونباخ Coefficient Alpha Cronbach's. جدول (I T)

ثبات مقياس السلوك العدوانى بتطبيق معامل ألفا كرونباخ

$10=0$

\begin{tabular}{|c|c|c|c|}
\hline معامل الثبات & وحدة القياس & الأبعـاد & \\
\hline *. & درجة & السلوك العدوانى نحو الذات & \multirow{3}{*}{7} \\
\hline *..TrV & 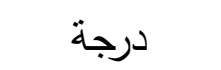 & السلوك العدوانى نحو الآخرين & \\
\hline$* . .771$ & درجة & السلوك العدوانى فى تجاه الأشياء والممتلكات & \\
\hline$*$ * . TV0 & درجة & المقياس ككل & \\
\hline
\end{tabular}

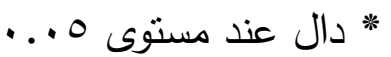

قيمة "ر" الجدولية عند مستوى معنوية 0 . . = = ؛ 01.

مجلة بحوث التربية الثاملة _ كلية التربية الرياضية للبنات- جامعة الزقازيق ـ المجلد الثانيـ للنصف الأول للأبحاث العلميةـ 1 I ـ rم 
-49 -

تأثير برنامج إرشادى على بعض المتغيرات البننية والمهارية في الكرة الطائرة وخفض حدة السلوك العدوانى لاى الأطفال المعاقين ذهنيا القابلين للتُعلم

يتضـح مـن جدول (T I ) أن معامـل الثبـات بتطبيق معامـل ألفا كرونبـاخ قد حقق قيمـة قدرها

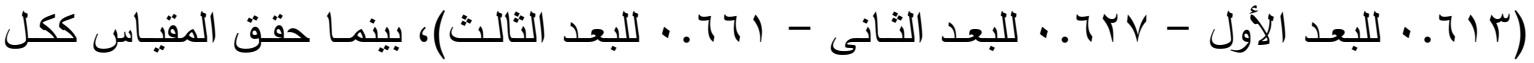

ه T . . ، وهذه يدل على أن السلوك العدوانى وأبعاده المختلفة على قدر من الثبات يوثق به.

ثم قام الباحث بحساب ثبات مقياس السلوك العدوانى باستخدام التجزئة النصفية (Split-Half)

عن طريـق تجزئـة عبارات كل محور وعبارات المقياس ككل (العبارات الفرديـة - العبارات الزوجية)

وإيجاد معامل الارتباط بين الجزأين، كما يوضحه جدول (ع ().

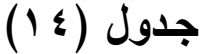

ثبات مقياس السلوك العدوانى باستخدام التجزئة النصفية

$10=\dot{0}$

\begin{tabular}{|c|c|c|c|c|c|c|c|}
\hline \multirow{2}{*}{ 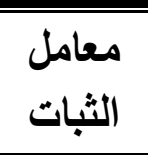 } & \multicolumn{2}{|c|}{ العبارات الزوجية } & \multicolumn{2}{|c|}{ العبارات الفردية } & \multirow{2}{*}{ | وحدة } & \multirow{2}{*}{\multicolumn{2}{|c|}{ الأبعـاد }} \\
\hline & ${ }^{r} \varepsilon \pm$ & سَنَ & ${ }^{\prime} \varepsilon \pm$ & سنَ & & & \\
\hline$*$ *.V人 & ה & 18.0 & $.7 \leq 0$ & IV.V. & درجة & السلوك العدوانى نحو الذات & \\
\hline$* . \wedge 11$ & $.0 \%$ & r I.r & $.0 Y V$ & rI. KA & درجة & السلوك العدوانى نحو الآخرين & $\bar{z}$ \\
\hline$*$ * . TV0 & וזr.. & $17 . r \leq$ & $. r \leqslant r$ & 17.0. & درجة & والسملوك العدوانى فى تجاه الأشياء & \\
\hline$* . \vee \vee q \varepsilon$ & r.. 19 & $191.7 \varepsilon$ & Y.YIV & $\begin{array}{c}191.1 \\
1\end{array}$ & درجة & المقياس ككل & \\
\hline
\end{tabular}

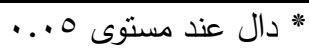

قيمة "ر" الجدولية عند مستوى معنوية .0. . = ؛ ؛ 0.0

يتضـح مـن جدول (ع ا) أن قيمـة معامـل الارتبـاط بين العبـارات الفرديـة والزوجيـة لمحساور

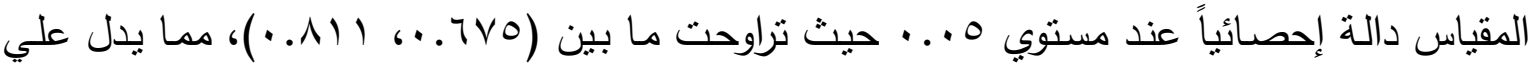

أن مقياس السلوك العدوانى يتميز بدرجة كبيرة من الاستقرار والثبات.

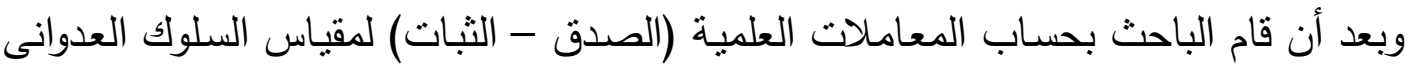

أصبح فى صورته النهائية جاهز للتطبيق على عينة البحث الأساسية حيث اشتملت عباراته على عدد (70) عبارة موزعة على ثلاثة أبعاد، ويتم الإجابة على عبارات المقياس من خلال ميزان ثلاتى (كثيراً

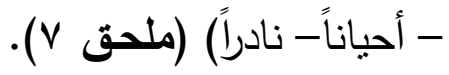

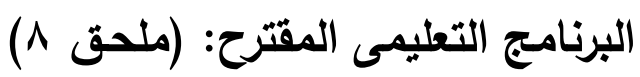

قام الباحث بوضـع البرنـامج الإرشـادى المقترح على بعض المتغيرات البدنية ومهارات الكرة

الطائرة قيد البحث لخفض حدة السـوك العدوانى باستخدام الأنشطة الرياضية والتمرينـات والألعاب الصغيرة، وذلك في ضوء خصائص النمو لهذه المرحلة السنية وفى ضوء المنهج الدراسى وقد وضع بـ بـ البرنامج على الأسس والخطوات التالية:

مجلة بحوث التربية الثاملة ـ كلية التربية الرياضية للبناتـ جامعة الزقازيق ـ المجلد الثاني- للنصف الأول للأبحاث العلميةـ 1 ا ـ بم 
يهدف البرنامج إلي التعرف على تأثير برنامج إرشادى على بعض المتغيرات البدنية ومهارات

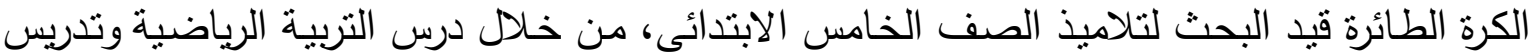

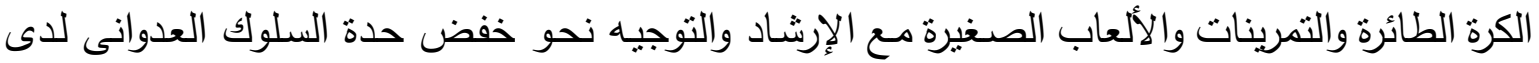
الأطفال المعاقين ذهنيا القابلين للتعلم.

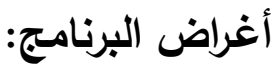

اعتماداً على ما أثنارت إليه القراءات النظرية والدراسات السابقة تم تحديد الأغراض الآتية:

1 أن يستطيع الطفل التعبير عن نفسه من خلال أنشطة البرنامج.

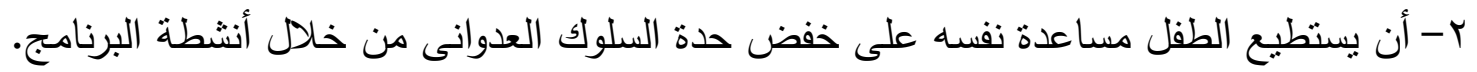
ب- أن يمارس الطفل أنشطة مختلفة ومتتوعة تسهم في تتمية قدراته البدنية والمهارية. ع - أن يعرف الطفل أهمية ممارسة النشاط الرياضي والحفاظ على صحته الطنه وقوامه.

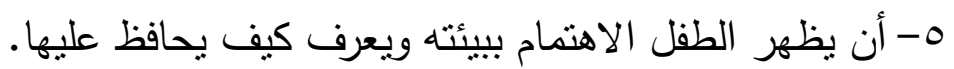
ج-أن يزود الطفل بالخبرات اللازمة بهدف التأثير في معلوماته وعاداته المتعلقة بالسلوك العدواني.

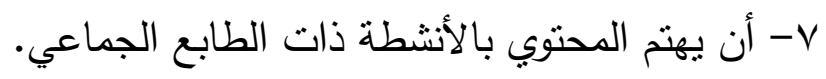

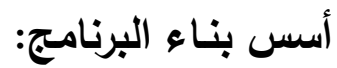

عند وضع البرنامج المقترح قام الباحث بمراعاة الأسس التالية: • أن يحقق البرنامج الهدف منه ويكون في مستوي قدرات الأطفال.

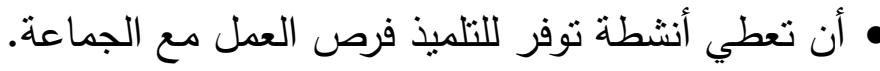

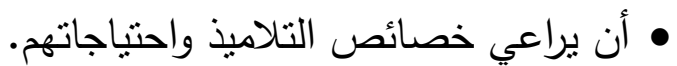
• أن براعي الفروق الفردية بين الأطفال.

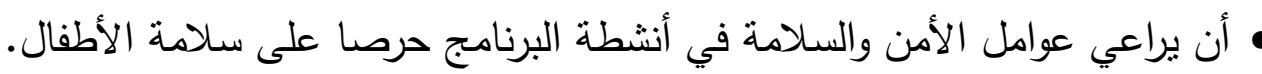
• أن ترتبط أنشطة البرنامج بحياة الأطفال وبيئتهم المدرسية والاجتماعية. • أن أنتاسب الأنشطة المختارة مع المرحلة السنية.

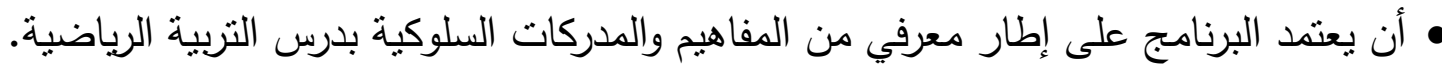
• أن يساعد البرنامج إثباع حاجة الطفل من الحركة والنشاط. أن يحقق محتوي البرنامج الإرشادي (تتمية المتغيرات البدنية - تعلم بعض مهارات البنات الكرة الطائرة خفض حدة السلوك العدوانى).

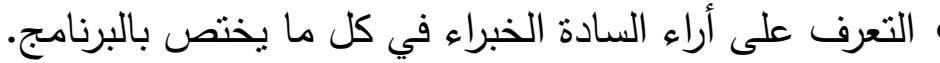

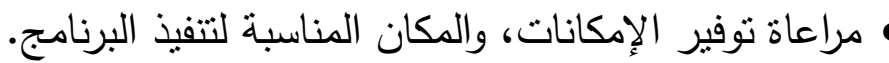

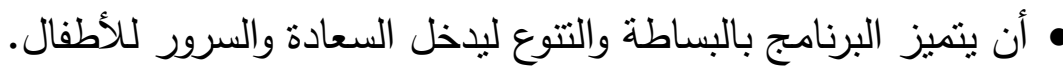
• أن يتيح الفرصة للاشتراك والممارسة لكل التلاميذ. 
- $\leqslant 1-$

تأثير برنامج إرشادى على بعض المتغيرات البذنية والمهارية في الكرة الطائرة وخفض حدة السلوك العدوانى لاى الأطفال المعاقين ذهنيا القابلين للتعلم الإطار الزمنى للبحث:

قام الباحث بوضـع دروس التربية الرياضية لتعليم مهارات الكرة الطائرة قيد البحث باستخدام

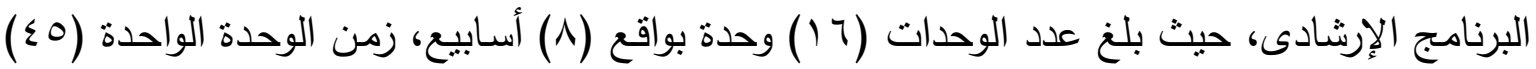

جدول (10)

دقيقة، كما يوضحه جدول (10).

زمن الوحدة التعليمية

\begin{tabular}{|c|c|c|}
\hline الزمن & أجزاء الوحدة & \\
\hline اق & الإحماء والأعمال الإدارية & \multirow{2}{*}{ الجزء التمهيدي } \\
\hline . اق & الإعداد البدني & \\
\hline \multirow{2}{*}{ • } & النشاط التعليمي & \multirow{2}{*}{ الجزء الرئيسي } \\
\hline & النشاط التطبيقي & \\
\hline مق & الختام & الجزء الختامي \\
\hline
\end{tabular}

من أجل تقوبم البرنامج التعليمي باستخدام البرنامج الإرشادى قام الباحث بالآتى:

- استخدام مجموعة من الاختبارات البدنية المرتبطة بمهارات الكرة الطائرة قيد البحث. - استخدام مجموعة من الاختبارات المهارية لقياس مهارات الكرة الطائرة قيد البحث. - تطبيق مقياس السلوك العدوانى. القياسات القبليـة:

قام الباحث بإجراء القياسـات القبليـة للمجموعتين التجريبيـة والضـابطة فى بعض المتغيرات

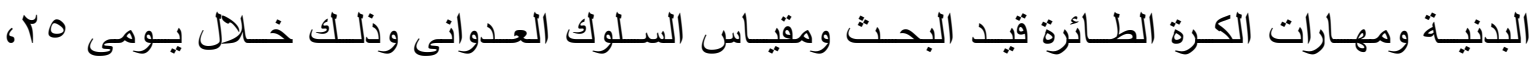
T القياسات القبلية لمجموعتى البحث، كما يوضحه جدول (1 ( ) 
$-\Sigma r_{-}$

تأثير برنامج إرشادى على بعض المتغيرات البذنية والمهارية في الكرة الطائرة وخفض حدة السلوك العدوانى لاى الأطفال المعاقين ذهنيا القابلين للتعلم

جدول (17)

دلالة الفروق الإحصائية بين القياسات القبلية للمجموعتين التجريبية والضابطة فى بعض المتغيرات البذنية ومهارات الكرة الطائرة قيد البحث ومقياس السلوك العدوانى

$1 \Lambda=r \dot{r}=1 \dot{0}$

\begin{tabular}{|c|c|c|c|c|c|c|c|}
\hline \multirow{2}{*}{ "َّمحة "توبة" } & \multicolumn{2}{|c|}{ الضابطة } & \multicolumn{2}{|c|}{ التجريبية } & \multirow{2}{*}{ | القياس } & \multirow{2}{*}{\multicolumn{2}{|c|}{ المتغيرات }} \\
\hline & $\varepsilon \pm$ & سنr & $\varepsilon \pm$ & سََر & & & \\
\hline.$\leqslant 0$. & I.rTO & $\Lambda . Y \xi$ & $1.1 \leqslant \varepsilon$ & $\Lambda . r v$ & ثنانية & |العدو • بَم من البدء العالي & \\
\hline $.1 \leqslant 9$ & $\varepsilon . \leqslant 0$. & IIT.Y7 & $\varepsilon . \mu q V$ & $11 \% .1$. & سم & الوثب العريض من الثبات & \\
\hline .701 & $.90 \leqslant$ & 9.10 & $.9 Y V$ & $V_{.} \cdot$ & ثانية & ثنى الذر اعين من الانبطاح المائل & \\
\hline & 1.71 & $I V . r$ & 1.110 & IV.IT & ثانية & الجرى الزجز اجى بطريقة باور & \\
\hline .114 & $.9 \leq \wedge$ & Y. $\leqslant 7$ &.$\wedge \vee T$ & $r . \varepsilon r$ & سم سم & ثني الجذع من الوقوف & \\
\hline.$Y Y T$ & $1.70 \%$ & $1 . .49$ & 1.749 & $1 \cdot r \cdot$ & ثانية & الدو ائر المرقمة & \\
\hline. .YYT & .970 & $\varepsilon . Y$. & $\cdot \wedge \wedge r$ & $\varepsilon .10$ & | درجة & التمرير من أسفل بالساعدين & $\overline{7}$ \\
\hline.$Y V \varepsilon$ & I.ruq & $0 . V$. & 1.700 & $0 . \wedge$. & | درجة & التمرير من أعلي وللامام & \\
\hline$\because 149$ & 1.011 & $\varepsilon . \wedge$. & $1.7 \lambda r$ & $\varepsilon . \vee 0$ & درجة & الإرسال الامامي المو اجه من أسفل & \\
\hline 1.495 & r.YTA & or.1. & T.17V & 01.10 & | درجة & السلوك العدو انى نحو الذات & \\
\hline $1.7 \cdot 1$ & r.IV乏 & Ar.ro & r. rTo & AT.O. & درجة & السلوك العدو انى نحو الآخرين & का \\
\hline 1.94 & $.90 r$ & rq.0. & $\cdot 9 \wedge 7$ & rq.Vo & | درجة & 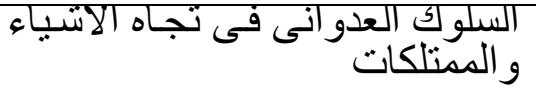 & \\
\hline $1.1 \mathrm{VT}$ & Y.OVA & IVT.AO & r.79r & $1 V \leqslant .7$. & | درجة & مقياس السلوك العدوانى ككل & \\
\hline
\end{tabular}

يتضـح مـن جدول (7 ( ) عدم وجود فروق دالة إحصـائيا بين القياسـات القبليـة للمجموعتين التجربيية والضـابطة فى بعض المتغيرات البدنية ومهارات الكرة الطائرة قيد البحث ومقياس السلوك العدوانى، مما يشير إلى تكافؤ المجموعتين فى هذه المتغيرات.

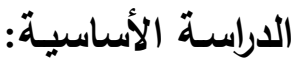

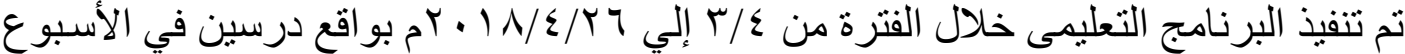

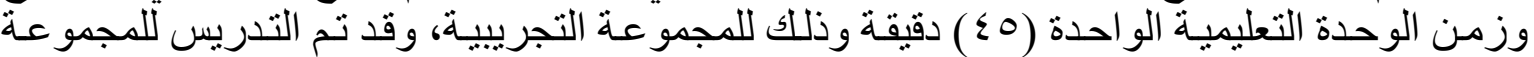

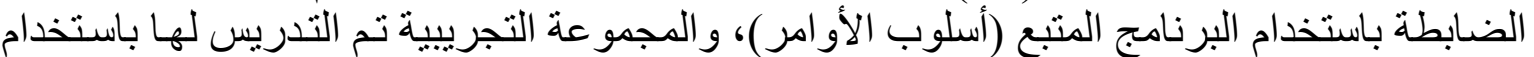

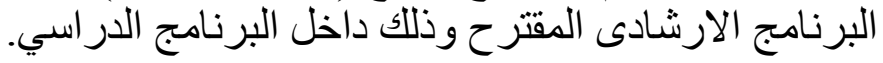

القياسـات البعديـة:

تم إجراء القياسات البعدية للمجموعتين التجريبية والضـابطة بعد الانتهاء من تطبيق البرنامج

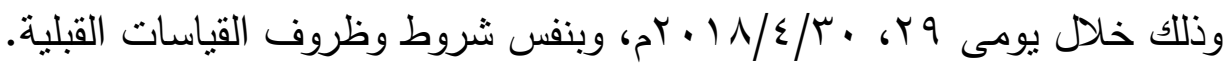
المعالجات الإحصائيةة:

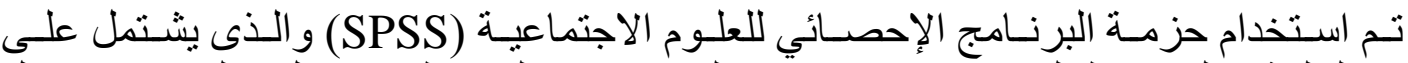

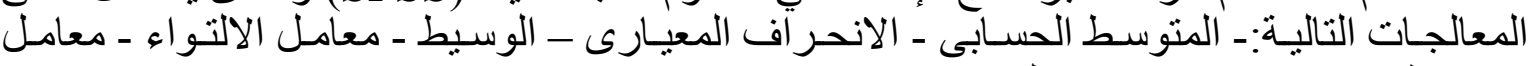

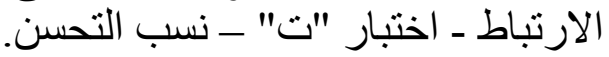

مجلة بحوث التربية الثاملة ـ كلية التربية الرياضية للبنات- جامعة الزقازيق ـ المجلد الثانيـ للنصف الأول للأبحاث العلميةـ 1 1 ـ rم 
تأثير برنامج إرشادى على بعض المتغير ات البذنية والمهارية في الكرة الطائرة وخفض حدة السلوك العدوانى لدى الأطفال المعاقين ذهنيا القابلين للتعلم

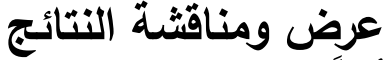
أولاً: عرض النتائج

جدول (Iv)

دلالة الفروق الإحصائية بين القياسات القبلية والبعدية للمجموعة التجريبية في المتغيرات البدنية قيد البحث

\begin{tabular}{|c|c|c|c|c|c|c|}
\hline \multirow{2}{*}{ قالمحسوية "ت } & \multicolumn{2}{|c|}{ القياس البعدى } & \multicolumn{2}{|c|}{ القياس القبلى } & \multirow{2}{*}{ |لقدة } & \multirow{2}{*}{ المتغيرات } \\
\hline & $\varepsilon \pm$ & سَن & $\varepsilon \pm$ & سنَ & & \\
\hline *O.YYO & . & 7.19 & $1.1 \leq \varepsilon$ & A.rv & ثانية & العدو • بام من البدء العالي \\
\hline$* \leqslant .70 \leqslant$ & س & IN.r & $\varepsilon . r q \vee$ & $11 T .1$. & 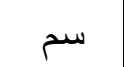 & الوثب العريض من الثبات \\
\hline$* 0 . r \leq 1$ &. tr人 & A. Yo & $.9 Y V$ & $v \ldots$ & 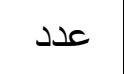 & ثنى الذراعين من الانبطاح المائل \\
\hline$* \varepsilon . \cdot V r$ & . . हा & 10.91 & 1.140 & IV.IT & ثانية & الجرى الزجزاجى بطريقة باور \\
\hline$* 0 . \leqslant q$. & $\cdot r \leq r$ & r.7 &.$\wedge \vee 7$ & $r . \varepsilon r$ & سم & ثني الجذع من الوقوف \\
\hline *r.AYo & .701 & A. $7 \mathrm{~V}$ & 1.749 & I.r. & ثانية & الدوائر المرقمة \\
\hline
\end{tabular}

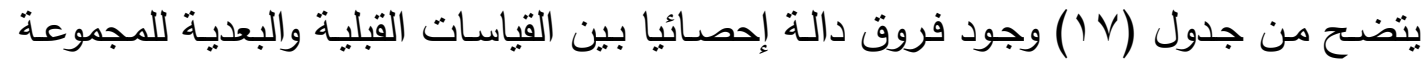
التجربيية فى بعض المتغيرات البدنية قيد البحث لصالح القياسات البعدية. جدول (11)

دلالة الفروق الإحصائية بين القياسات القبلية والبعدية للمجموعة الضابطة فى المتغيرات البدنية قيد البحث البه

$1 \wedge=\dot{0}$

\begin{tabular}{|c|c|c|c|c|c|c|}
\hline \multirow{2}{*}{ قيمة "ث" } & \multicolumn{2}{|c|}{ القياس البعدى } & \multicolumn{2}{|c|}{ القياس القبلى } & \multirow{2}{*}{ وحدة } & \multirow{2}{*}{ المتغيرات } \\
\hline & ${ }^{r} \varepsilon \pm$ & سنَr & ${ }^{\prime} \varepsilon \pm$ & 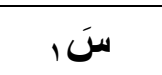 & & \\
\hline *T.YTH & $\cdot . \leqslant T$ & V.or & 1.rmo & $\Lambda . r \leq$ & ثانية & العدو • بام من البدء العالي \\
\hline *Y.r & Y.7I $\leqslant$ & 117.1. & $\varepsilon . \leqslant 0$. & 11T.r7 & 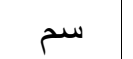 & الوثب العريض من الثبات \\
\hline 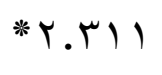 & $\because \sum \wedge T$ & V.Vo & $.90 \leqslant$ & $V .10$ & 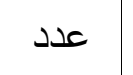 & ثنى الذراعين من الانبطاح المائل \\
\hline$* Y . \mid \wedge \wedge$ & ( & $17 . \varepsilon$. & $1 .+71$ & $1 \mathrm{~V} \cdot \mathrm{r}^{2}$ & ثانية & الجرى الزجزاجى بطريقة باور \\
\hline *r.r. &. $.01 Y$ & r. & $\cdot .9 \leq 1$ & $r . \varepsilon\urcorner$ & سم & ثني الجذع من الوقوف \\
\hline (Tוז & $\because .9 \leq V$ & q.r. & 1.704 & $1 . .49$ & ثانية & الدوائر المرقمة \\
\hline
\end{tabular}

يتضح من جدول (1 ( ) وجود فروق دالة إحصائيا بين القياسـات القبلية والبعديـة للمجموعة الضابطة فى بعض المتغيرات البدنية قيد البحث لصالح القياسات البعدية. 
$-\leq \varepsilon-$

تأثير برنامج إرشادى على بعض المتغيرات البذنية والمهارية في الكرة الطائرة وخفض حدة السلوك العدوانى لاى الأطفال المعاقين ذهنيا القابلين للتعلم

جدول (19)

دلالة الفروق الإحصائية بين القياسات القبلية والبعدية للمجموعة التجريبية

في بعض مهارات الكرة الطائرة قيا البحث البط لهابه

$1 \Lambda=\dot{0}$

\begin{tabular}{|c|c|c|c|c|c|c|}
\hline \multirow{2}{*}{ قيمة "تحسوية } & \multicolumn{2}{|c|}{ القياس البعدى } & \multicolumn{2}{|c|}{ القياس القبلى } & \multirow{2}{*}{ |لقياس } & \multirow{2}{*}{ المتغيرات } \\
\hline & $\varepsilon \pm$ & 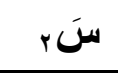 & $\varepsilon \pm$ & سََا & & \\
\hline$* q . \vee 7 \vee$ & $.70 \mathrm{r}$ & 7.10 &.$\wedge \wedge r$ & $\varepsilon .10$ & درجة & التمرير من أسفل بالساعدين \\
\hline$* 0 . \leqslant Y\}$ & $\cdot .119$ & 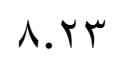 & 1.700 & 0.1 & درجة & التمرير من أعلي ولأكام \\
\hline$* V \cdot r \cdot O$ & $1 . . \wedge 7$ & A. Yo & $1.7 \wedge r$ & $\varepsilon . v_{0}$ & | درجة & الإرسال الأمامي المواجه من أسفل \\
\hline
\end{tabular}

يتضح من جدول (9 (1) وجود فروق دالة إحصائيا بين القياسات القبلية والبعدية للمجموعة القية

التجريبية فى بعض مهارات الكرة الطائرة قيد البحث لصالح القياسات البعدية.

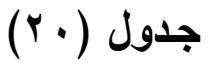

دلالة الفروق الإحصائية بين القياسات القبلية والبعدية للمجموعة الضابطة

فى بعض مهارات الكرة الطائرة قيد البحث لإليج

$1 \wedge=\dot{0}$

\begin{tabular}{|c|c|c|c|c|c|c|}
\hline \multirow{2}{*}{ قالمسمة "تية } & \multicolumn{2}{|c|}{ القياس البعدى } & \multicolumn{2}{|c|}{ القياس القبلى } & \multirow{2}{*}{ |لقياس } & \multirow{2}{*}{ المتغيرات } \\
\hline & $\varepsilon \pm$ & سَنَ & $\varepsilon \pm$ & سََ & & \\
\hline *Y.TI. & $\cdot . \wedge 17$ & $0 . .$. & .970 & $\varepsilon . r_{\text {. }}$ & درجة & التمرير من أسفل بالساعدين \\
\hline$* \Gamma . \Sigma V \Gamma$ & .910 & V.l. & 9 & $0 . V$. & درجة & التمرير من أعلي وللأمام \\
\hline$* r . \wedge r$ & I.TI & T.r. & 1.011 & $\varepsilon . \wedge$. & درجة & الإرسال الأمامي المواجه من أسفل \\
\hline
\end{tabular}

يتضح من جدول (· r) وجود فروق دالة إحصائيا بين القياسات القبلية والبعديـة للمجموعة

الضابطة فى بعض مهارات الكرة الطائرة قيد البحث لصالح القياسات البعدية.

مجلة بحوث التربية الثاملة ـ كلية التربية الرياضية للبناتـ جامعة الزقازيق ـ المجلد الثاني- للنصف الأول للأبحاث العلميةـ 1 ا ـ بم 
$-\leqslant 0$

تأثير برنامج إرشادى على بعض المتغيرات البذنية والمهارية في الكرة الطائرة وخفض حدة السلوك العدوانى لاى الأطفال المعاقين ذهنيا القابلين للتعلم

جدول (1)

دلالة الفروق الإحصائية بين القياسات القبلية والبعدية للمجموعة التجريبية

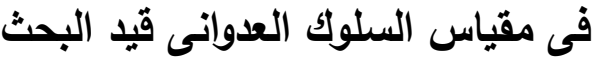

$1 \wedge=\dot{0}$

\begin{tabular}{|c|c|c|c|c|c|c|}
\hline قيمة "ت" & 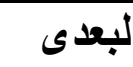 & القياس & 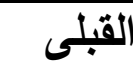 & القياس & وحدة & " \\
\hline المحسوية & $\varepsilon \pm$ & سنَr & $\varepsilon \pm$ & سَّ & القياس & \\
\hline$* 11.009$ & $1.97 \mathrm{~V}$ & $\varepsilon r .0$. & T.17V & $01 . r 0$ & درجة & السلوك العدوانى نحو الذات \\
\hline$* \nearrow . \wedge \varepsilon r$ & T.ITE & VI... & r.YTo & NT.O. & درجة & السلوك العدوانى نحو الآخرين \\
\hline$* 17 . . \vee$. & $1 . r \leqslant 0$ & ס ס.rm &. $.9 \wedge 7$ & rq.vo & درجة & والممتلكات العدوانى فى تجـاه الأشياء \\
\hline *Y1.701 & r.lV & $\begin{array}{c}\text { IOY.V } \\
0\end{array}$ & r. $79 r$ & $1 \vee \varepsilon .7$. & درجة & ل السلولك العدوانى ككل \\
\hline
\end{tabular}

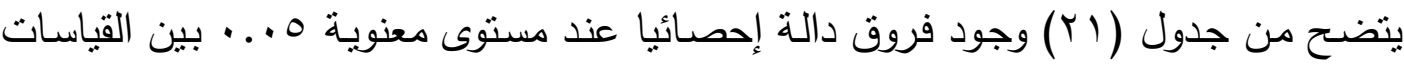

القبلية والبعدية للمجموعة التجريبية فى مقياس السلوك العدوانى قيد البحث لصالح القياسات البعدية.

جدول (Yr)

دلالة الفروق الإحصائية بين القياسات القبلية والبعدية للمجموعة الضابطة

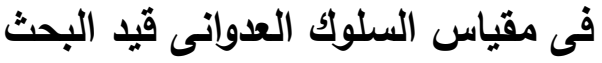

$1 \wedge=\dot{0}$

\begin{tabular}{|c|c|c|c|c|c|c|}
\hline قيمة "ت" & البعدى & القياس & القبلى - - القى & القياس & 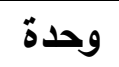 & 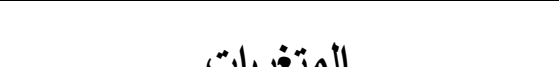 \\
\hline المحسوية & $\varepsilon \pm$ & 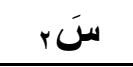 & $\varepsilon \pm$ & 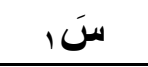 & القياس & \\
\hline$*$ *. & $r .1 \leq \Lambda$ & $\varepsilon 9 . \vee 0$ & r.YYA & or.l. & درجة & السلوك العدوانى نحو الذات \\
\hline *T.Y人T & T.Y19 & VA. 70 & $r . I V \varepsilon$ & Ar.ro & درجة & السلوك العدوانى نحو الآخرين \\
\hline *0.ก人 & $1.0 Y 7$ & TV.10 &. $.90 T$ & rq.0. & درجة & والممتلكات العدوانى فى تجـاه الأشـياء \\
\hline *V.YIY & $\Gamma .9 \wedge \varepsilon$ & $\begin{array}{c}170.0 \\
0\end{array}$ & Y.OVA & IVT.Ao & درجة & مقياس السلوك العدوانى ككل \\
\hline
\end{tabular}

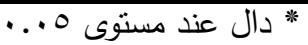

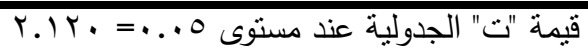

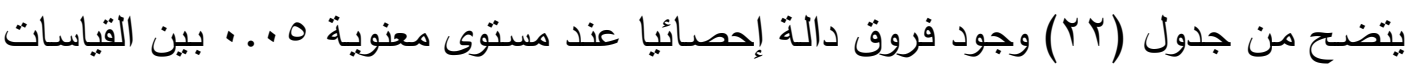

القبلية والبعدية للمجموعة الضابطة فى مقياس السلوك العدوانى قيد البحث لصالح القياسات البعدية.

مجلة بحوث التربية الثاملة ـ كلية التربية الرياضية للبناتـ جامعة الزقازيق ـ المجلد الثانيـ للنصف الأول للأبحاث العلميةـ 1 ا ـ Yم 
$-\leqslant 7-$

تأثير برنامج إرشادى على بعض المتغير ات البذنية و المهارية في الكرة الطائرة وخفض حدة السلوك العدوانى لاى الأطفال المعاقين ذهنيا القابلين للتعلم

$$
\text { جدول (rr) }
$$

دلالة الفروق الإحصائية بين القياسات البعدية المجموعتين التجريبية والضابطة في البئي

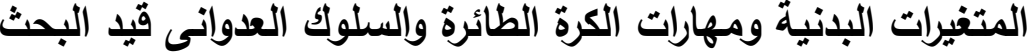

$1 \Lambda=r_{r} \dot{0}=1 \dot{0}$

\begin{tabular}{|c|c|c|c|c|c|c|c|}
\hline \multirow{2}{*}{ 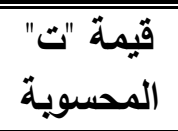 } & \multicolumn{2}{|c|}{ الضابطة } & \multicolumn{2}{|c|}{ التجريبية } & \multirow{2}{*}{ وحدة |لقباس } & \multirow{2}{*}{\multicolumn{2}{|c|}{ المتغيراث }} \\
\hline & ${ }^{r} \varepsilon \pm$ & سنَr & ' $\varepsilon \pm$ & سنَ & & & \\
\hline *V.oro & . . EY & V.or & ס ס & 7.19 & ثانية & العدو • مم من البدء العالي & \\
\hline$* \varepsilon . r \leq r$ & Y.7IE & 117.1 & I. & IN.rY & 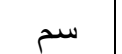 & الوثب العريض من الثبات & \\
\hline$* \varepsilon .9 \vee r$ &..$\leqslant \wedge 7$ & V.Vo & . & A. Yo & 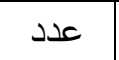 & ثنى الذراعين من الانبطاح المائل & 亏. \\
\hline$* 9.991$ & س & 17.2 & . I ו & $10.9 \mu$ & ثانية & الجرى الزجزاجى بطريقة باور & \\
\hline$* 0 . \vee 77$ & $.01 r$ & r. . 1 & $. . r \leqslant r$ & r. & 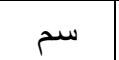 & ثني الجذع من الوقوف & \\
\hline$*$ r.YAV & $.9 \leq V$ & 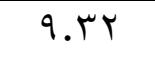 &. .701 & $1.7 \mathrm{~V}$ & ثانية & الدوائر المرقمة & \\
\hline$* q . V \vee$ &. .117 & $0 .$. &. $.70 \mathrm{r}$ & 7.10 & درجة & التمرير من أسفل بالساعدين & $\bar{y}$ \\
\hline$* 0.1 \leqslant \varepsilon$ &. .910 & V.l. &. .119 & N.r. & درجة & التمرير من أعلي وللأكام & \\
\hline$* 7.7 \leq 9$ & I.ru & ר.r. & 1.117 & N.ro & درجة & الإرسال الأمامي المواجه من أسفل & \\
\hline * & $r .1 \leqslant \Lambda$ & $\leqslant 9.10$ & $1.97 \mathrm{~V}$ & $\varepsilon r .0$. & درجة & السلوك العدوانى نحو الذات & $\overline{7}$ \\
\hline$*$ T. $\leqslant \leqslant 0$ & $r . r 19$ & VA. 70 & r.I E & VI... & درجة & السلوك العدوانى نحو الآخرين & अ \\
\hline$* 11.11$. & $1.0 Y 7$ & rV.10 & $1 . r \leqslant 0$ & סוץ." & درجة & والمدنلوك العـدوانى فـى تجـاه الأثـباء & $\frac{4}{17}$ \\
\hline$* 1 \leqslant .70 \leqslant$ & r.q人E & 170.00 & r. & lor.Vo & درجة & مقياس السلوك العدواتح ككل & \\
\hline
\end{tabular}

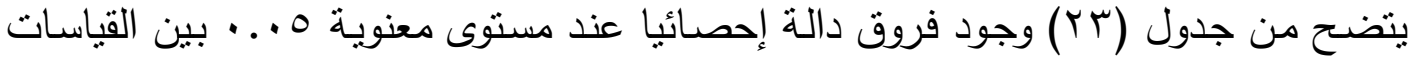

البعدية للمجموعتين التجريبية والضابطة فى بعض المتغيرات البدنية ومهارات الكرة الطائرة والسلوك

العدوانى قيد البحث لصالح المجموعة التجريبية.

$$
\text { جدول (r) }
$$

نسب التحسن بين القياس البعدى عن القبلى للمجموعتين التجريبية والضابطة

\begin{tabular}{|c|c|c|c|c|c|c|c|}
\hline معدل & نسب & بطة & الضا & سب & ريبية & التجر & \\
\hline التغيز & |التحسن \% & البعدى & القبلى & سن \% & البعدى & القبلى & \\
\hline r.. 0 & $q . \leqslant r$ & v.or & $\Lambda . Y \leq$ & Y I. $\leqslant \Lambda$ & $7 . \wedge 9$ & A.rV & العدو • سم من البدء العالي \\
\hline$\leqslant$ ร. . & r.01 & 117.1. & IIT.ry & $\leq 7.10$ & I11.TY & $11 \% .1$. & الوثب العريض من الثبات \\
\hline $9 . \leqslant \vee$ & $\Lambda . r q$ & 10 & $v .10$ & $\wedge\urcorner$ & ro & V... & إنثى الذراعين من الانبطاح المائل \\
\hline 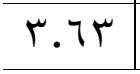 & r.A乏 & 17.5 & IV.er & $V . \Sigma V$ & $10.9 \pi$ & IV.IT & | الجرى الزجز| \\
\hline
\end{tabular}

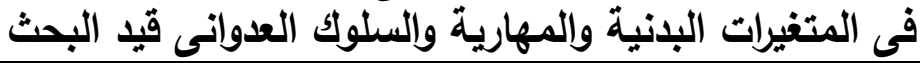


$-\Sigma V_{-}$

تأثير برنامج إرشادى على بعض المتغيرات البذنية والمهارية في الكرة الطائرة وخفض حدة السلوك العدوانى لاى الأطفال المعاقين ذهنيا القابلين للتعلم هابي

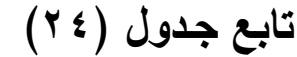

\begin{tabular}{|c|c|c|c|c|c|c|c|}
\hline \multirow{2}{*}{ التغير } & \multirow{2}{*}{ | نسب | } & \multicolumn{2}{|c|}{ الضابطة } & \multirow{2}{*}{ | نتحسب \% } & \multicolumn{2}{|c|}{ التجريية } & \multirow{2}{*}{ المتغيرات } \\
\hline & & البعدى & القبلى & & البعدى & القبلى & \\
\hline$r \leqslant .09$ & YO. Y. & $r . \wedge$ & T.ET & $\varepsilon 9 . \vee 9$ & $r .7 \varepsilon$ & r. $\Sigma T$ & ثني الجذع من الوقوف \\
\hline V.rt & $11 . \varepsilon \Lambda$ & q.rT & $1 . .4 q$ & $1 \wedge . \wedge \cdot$ & $1.7 \mathrm{~V}$ & I. r. & | الدوائر المرقمة \\
\hline$\varepsilon r .7$. & 19.0 & $0 .$. & $\varepsilon . Y$. & 74.70 & 7.10 & $\varepsilon .10$ & التمرير من أسفل بالساعدين \\
\hline IV.TE & $Y \leqslant .07$ & V.l. & $0 . V$. & $\leqslant 1.9$. & A.rT & 0.1 . & التمرير من أعلي وللأمام \\
\hline$\varepsilon r . \varepsilon r$ & r. ו. & ר.r. & $\varepsilon . \wedge$. & $\mathrm{VT.7N}$ & A. Yo & $\varepsilon . V_{0}$ & أسفل الإرسـال الأمـامي المواجـهـ مـن \\
\hline سז.rו & $\varepsilon . V Y$ & $\Sigma q . \vee 0$ & or.1. & $11 . .0$ & $\varepsilon r .0$ & $\begin{array}{c}01 . r \\
0\end{array}$ & السلوك العدوانى نحو الذات \\
\hline 0.19 & $\varepsilon .01$ & VA.70 & Ar.ro & $9 . \wedge V$ & VI. & Nr.o & و الآخرين \\
\hline $\mid r . . v$ & 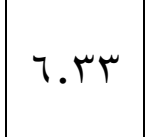 & rv. 10 & rq.०. & 19.00 & $\begin{array}{c}\text { T.t } \\
0\end{array}$ & $\begin{array}{l}\text { rq.V } \\
0\end{array}$ & 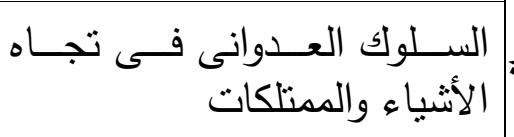 \\
\hline 9.19 & $0 . .1$ & 170.00 & VM.AO & IE.r. & IOY.VO & $V \varepsilon .7$. & المقياس العدوانى ككل \\
\hline
\end{tabular}

يتضح من جدول (§؟) وجود فروق فى معدل التغير بين نسب التحسن لكل من المجموعتين

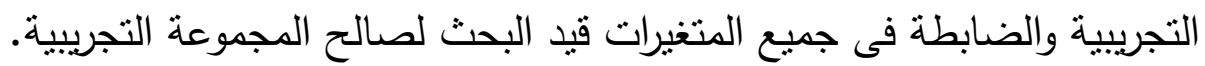
ثانياً: مناقشــة النتائسج:

يتضـح مـن نتائج جدول (V) ) وجـود فـروق دالـة إحصـائيا بـين القياسـات القبليـة والبعديـة للمجموعة التجريبية فى بعض المتغيرات البدنية (السرعة الانتقالية - القدرة العضلية للذراعين والرجلين - الرثـاقة - المرونـة - التوافق) لصـالح القياسـات البعديـة، ويرجـع الباحث ذلك إلى تأثنير البرنـامج الارشادى المقترح كان تأثيراً إيجابياً حيث احتوي البرنامج علي تمرينات وألعاب مقننة وموجهة لتنمية مكونات اللياقة البدنية الخاصة برياضة الكرة الطائرة الأمر الذى ساعد أطفال المجموعة التجربيية علي المشاركة الإيجابية وبذل الجهد في الأداء بصورة مختصرة لهم وفقاً لإمكانياتهم البدنية والنفسية.

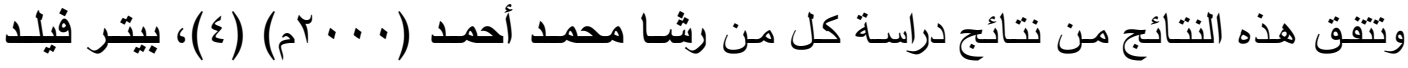
Butter field حمودة البنا (1 . . rم) (9) علي أن برامج الألعاب وبرامج التربية الحركية للمعاقين سمعياً والأسوياء لها تأثيراً إيجابي علي مستوى الأداء البدني. يتضـح مـن نتائج جـدول (1) ( ) وجـود فـروق دالـة إحصـائيا بـين القياسـات القبليـة والبعديـة للمجموعة الضابطة فى بعض المتغيرات البدنية (السرعة الانتقالية - القدرة العضلية للذراعين والرجلين - الرشاقة - المرونة- التوافق) لصالح القياسات البعدية، ويعزي الباحث هذا الفرق بين القياسين القبلي 
$-\Sigma \Lambda$ -

تأثير برنامج إرشادى على بعض المتغيرات البلنية والمهارية في الكرة الطائرة وخفض حدة السلوك العدوانى لاى الأطفال المعاقين ذهنيا القابلين للتعلم

والبعدى في متغيرات (السرعة الانتقالية - القدرة العضلية للذراعين والرجلين - الرشاقة - التوافق -

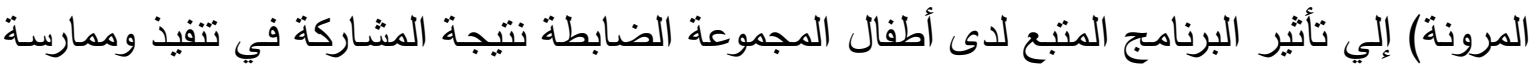
الأنشطة بالبرنامج المدرسي.

وبذللك يتحقق صحة الفرض الأول والذى ينص على " توجد فروق ذات دلالـة إحصائية بين القياسات القبلية والبعدية للمجموعتين التجريبية والضابطة فى بعض المتغيرات البدنية قيد البحث لصالح القياسات البعدية ".

يتضـح مـن نتـائج جدول (9 ( ) وجـود فـروق دالـة إحصـائيا بـين القياسـات القبليـة والبعديـة للمجموعـة التجريبيـة فى بعض مهارات الكرة الطائرة قيد البحث لصـالح القياسـات البعديـة، ويرجـع الباحث ذلك التحسن لدى أطفال المجموعـة التجريبيـة إلى استخدام البرنـامج التعليمى المقترح الذى ساعد على إثارة اهتمام المتعلم وتحفيزه على بذل الجهد في التعلم وعدم شعوره بالملل والفهح الجيد

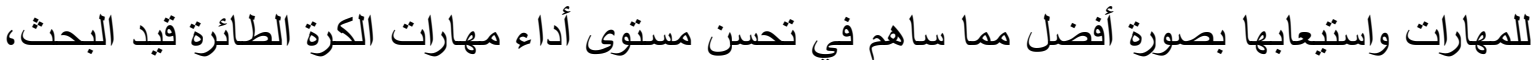
كما راعا البرنامج تقسيم المهارات إلى أجزاء صغيرة فى ضوء التسلسل المنطقى لها بطريقة منظمة ومتتابعة، مما سـاعد المتعلم على تكوين صورة واضحة عن المهارة وتفهم كل جزء وتعلمـه بطريقة سهلة وميسره.

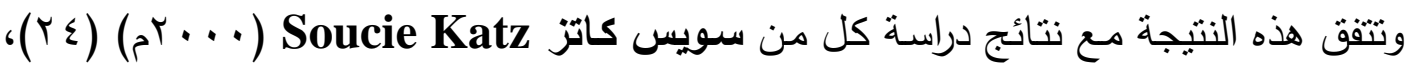

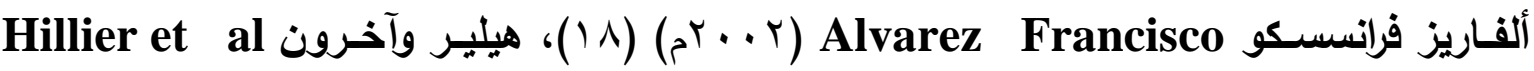

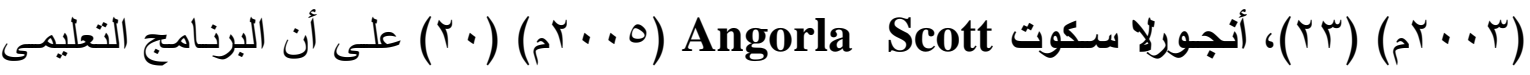
المقترح بما يمتلكه من إمكانيات متتوعة ومتميزة يمكن أن نزيد من فاعلية الطربقة التعليميـة وأيضاً

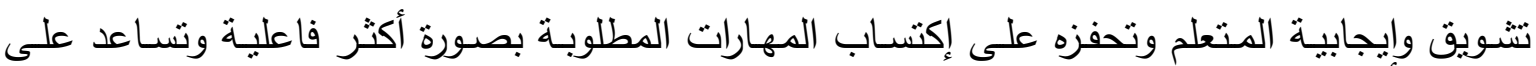
تحقيق الجانب الوجدانى للمتعلمين حيث أن البرنامج يتيح للتلميذ الفرصة بالاشتراك بفاعلية فى العملية التعليمية وذلك من خلال انتقال عملية التعلم من المعلم إلى التلميذ، كما أنه يراعى مبدأ الفروق الفردية بلية

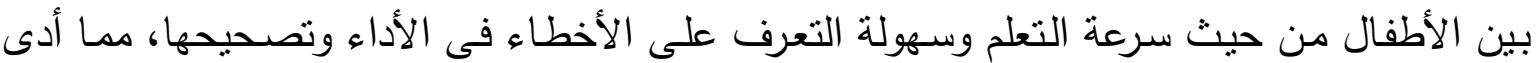
إلى زيادة دافعية الأطفال نحو الإجادة فى التعلم.

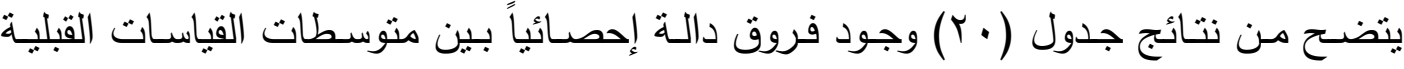
والبعديـة للمجموعة الضـابطة فى مهارات الكرة الطائرة قيد البحث ولصـالح القياسـات البعدية، ويرجع الباحث ذلك إلى إستخدام أسلوب الأوامر (الشرح والنموذج) لاى تلاميذ المجموعة الضابطة حيث يقوم المعلم بتدريس المهارات قيد البحث عملياً وتقديم الثرح اللفظى المبسط عن المهارات حتى يتمكن المتعلمين من تكوين تصور واضح عن الأداء المهارى المطلوب.

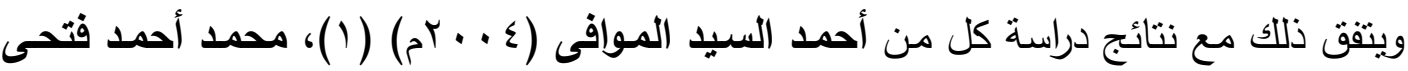

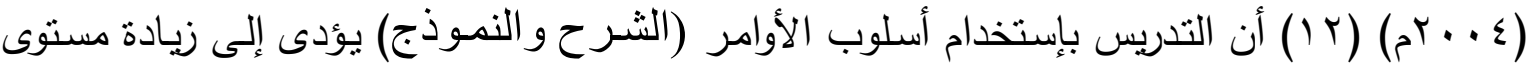
الفرد نتيجة للممارسة والأداء المتكرر والإسترجاع المباشر للمعلومات أثناء عملية التعلم. 
$-\leqslant 9-$

تأثير برنامج إرشادى على بعض المتنيرات البننية والمهارية في الكرة الطائرة وخفض حدة السلوك العدوانى لاى الأطفال المعاقين ذهنيا القابلين للتُعلم

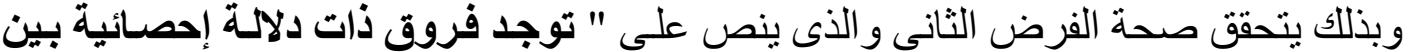

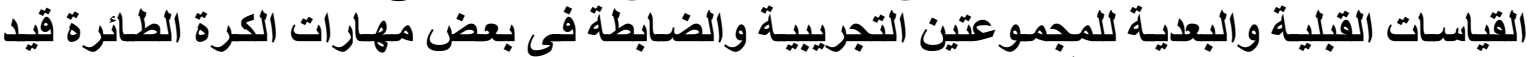

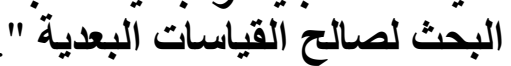

يتضـح مـن نتائج جدول (Y) (Y) وجود فروق دالة إحصـائيا عند مستوى معنويـة ه . . . بين

القياسـات القبلية والبعدية للمجموعة التجريبية فى خفض حدة السلوك العدوانى (نحو الذات - تجاه الآخرين - تجاه الأثياء والممتلكات) لصالح القياسات البعدية، ويرجع الباحث ذللك إلى تأثير البرنامج الارشادى المقترح لدى أطفال المجموعة التجريبية حيث تتوعت هذه الأنشطة بين نشاط (قصصى حركى - ترفيهى - ألعاب موسيقية - ألعاب طويلـة) ممـا كان لـه أثر في تفريخ الكبوتات الداخليـة للأطفال، وبالتالى خفض حدة سلوكهم العدوانى. وهذا يتفق مع الاتجاه العام السائد فى هذا المجال والذى يؤكد فاعلية البرنامج الارشـادى فى خفض حدة الاضطرابات السلوكية لدى الأطفال المعاقين ذهنياً القابلين للتعلم حيث تؤكد نتائج دراسات

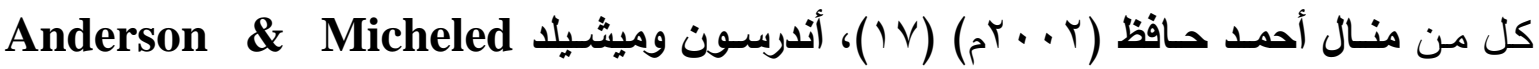
(T . . rم) (9 (1)على أهمية إتاحة الفرص والمواقف المختلفة التى تمكن الأطفال المعاقين عقلياً من

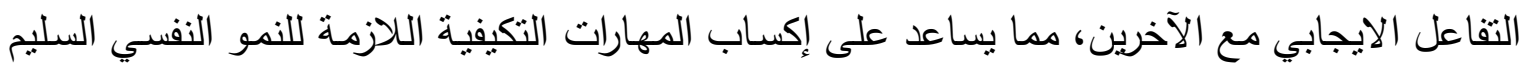

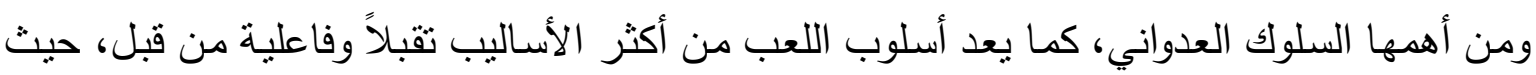

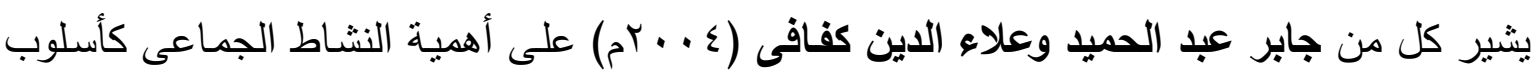

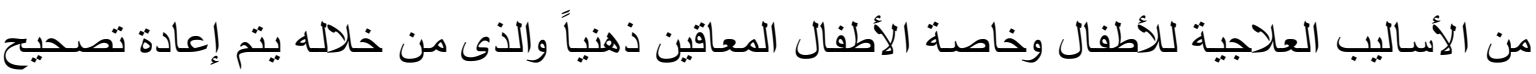

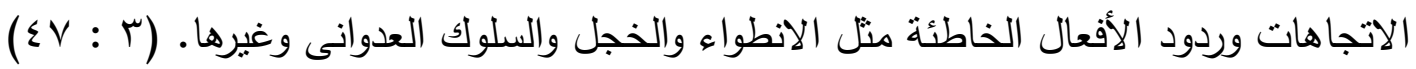

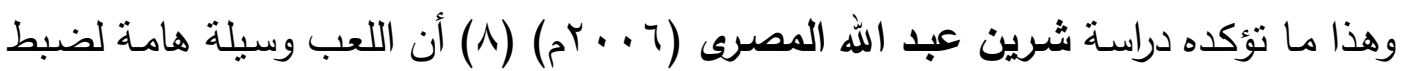
وتوجيه سلوك الطفل كما أن لها دور في التتفيس الانفعالي للطفل وتساعده على التعبير عن مشكلاته وصراعاته وتوفر للطفل الراحة النفسية وتقلل من العدوان لديه.

يتضـح مـن نتائج جدول (YY) وجود فروق دالة إحصـائيا عند مستوى معنويـة ه . . . بين القياسـات القبلية والبعديـة للمجموعة الضـابطة فى خفض حدة السلوك العدوانى (نحو الذات - تجاه الآخرين - تجاه الأشياء والممتلكات) لصالح القياسات البعدية، ويعزو الباحث ذلك إلى فاعلية البرنامج

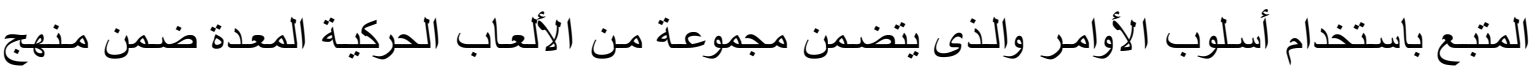
المرحلة الابتدائية من فبل الوزارة والتى تساعد على تعلم بعض المتغيرات البدنية والمهارية ومن خلال الأنشطة الجماعية للأطفال المعاقين ذهنيا القابلين للتعلم التى تعمل على تتمية المهارات الإجتماعية والتى تساعد بطبعها على خفض حدة السلوك العدوانى لديهم.

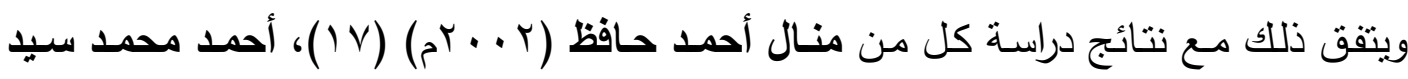

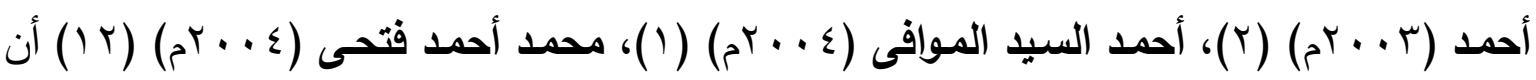
ممارسة الأنشطة الرياضية تتمى المعلومات والمعارف المتصلة بطبيعة النشاط الذى يمارسه الفرد، مما يؤدى بدوره إلى اكتساب الأنماط السلوكية الحميدة مثل النظام والطاعة والالتزام. 
-0 .

تأثير برنامج إرشادى على بعض المتغيرات البلنية والمهارية في الكرة الطائرة وخفض حدة السلوك العدوانى لاى الأطفال المعاقين ذهنيا القابلين للتعلم

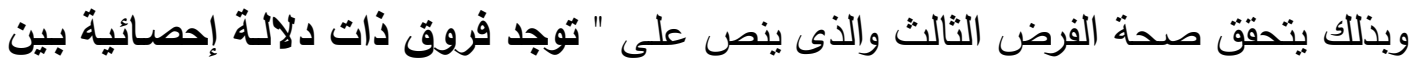

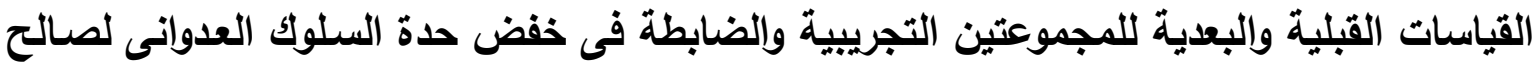

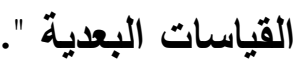

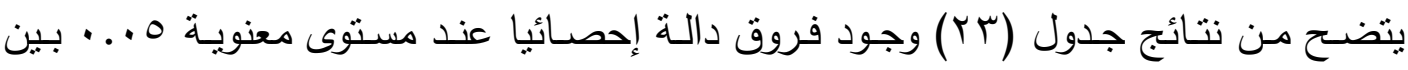

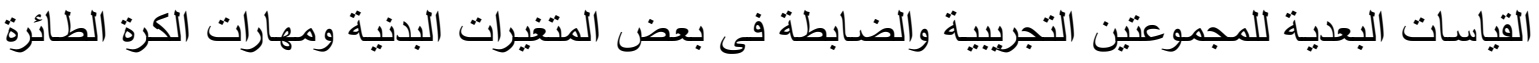

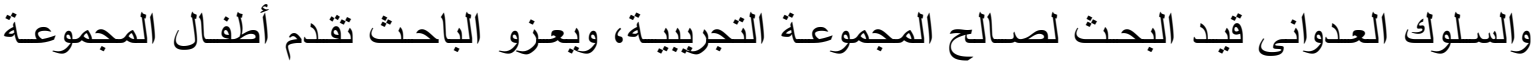

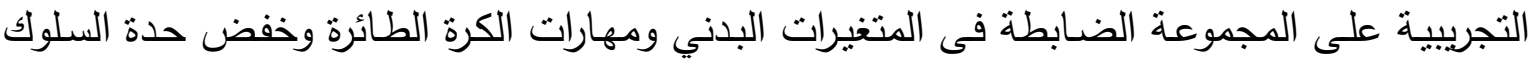

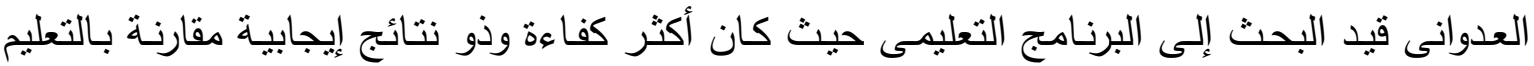

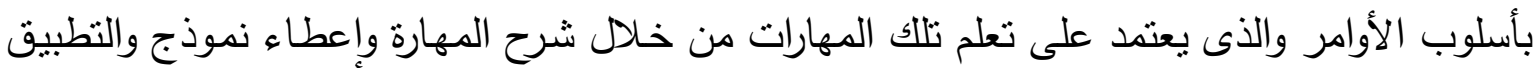

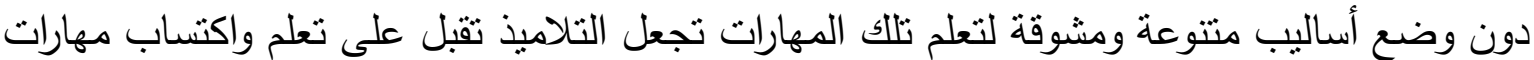

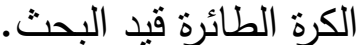

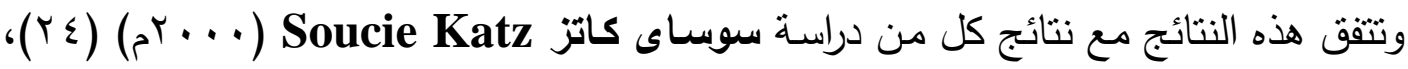

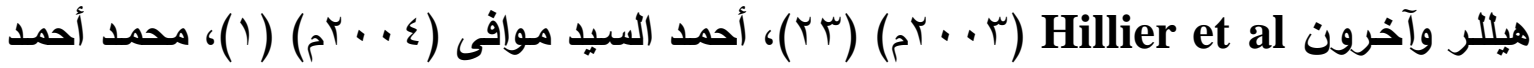

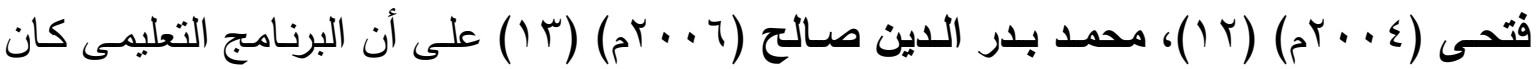

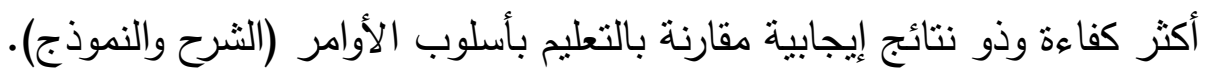

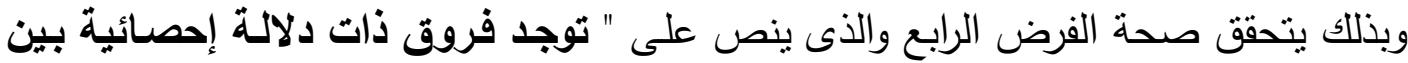

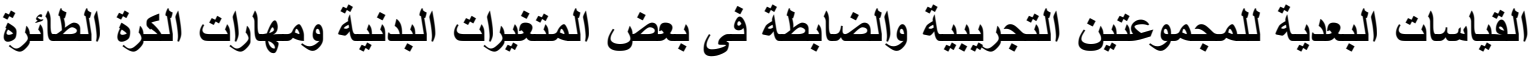
وخفض حدة السلوك العدوانى قيد البحث لصائح المجموعة التجريبية ".

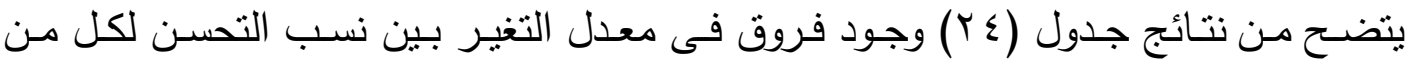

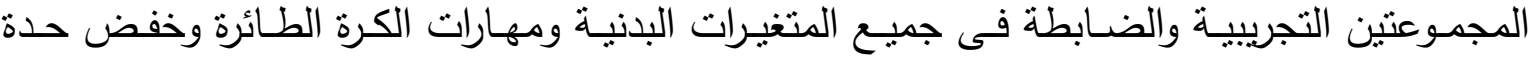

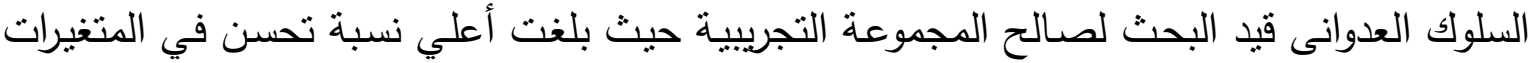

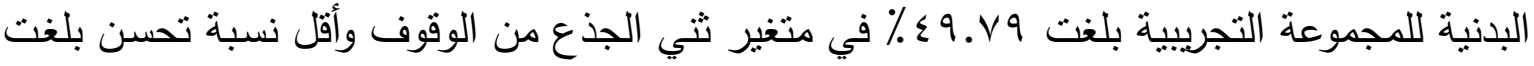

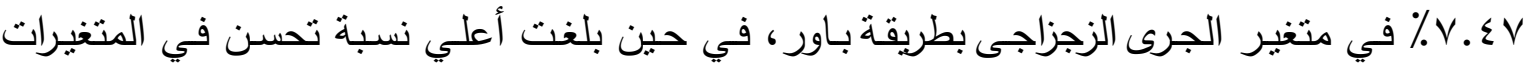

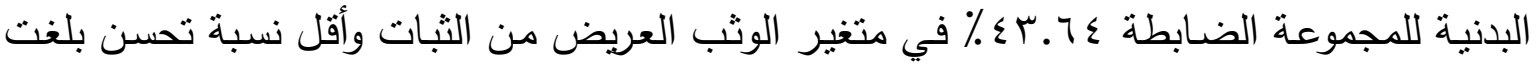

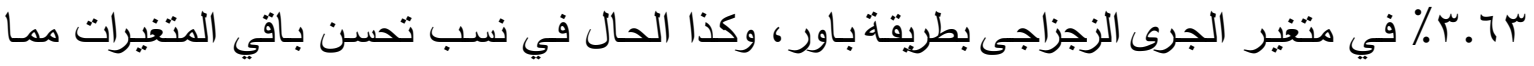

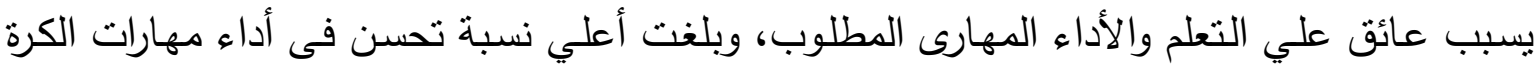

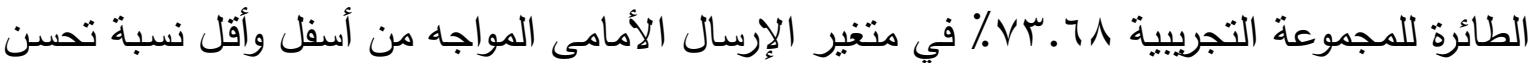

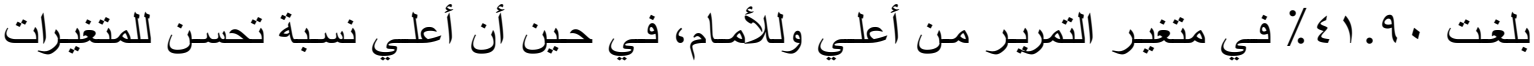

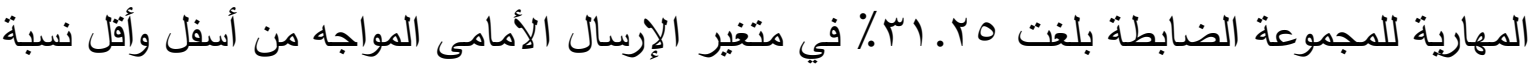

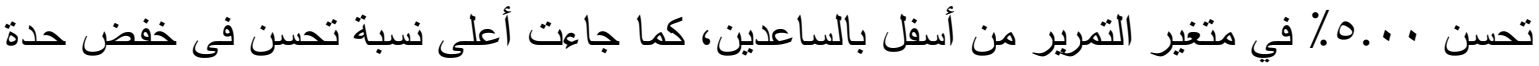

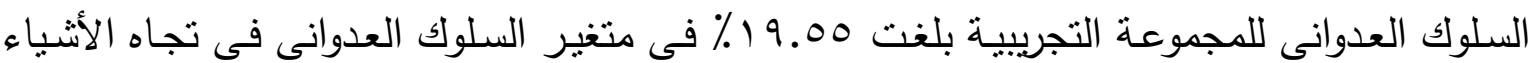


$-01-$

تأثير برنامج إرشادى على بعض المتغيرات البلنية والمهارية في الكرة الطائرة وخفض حدة السلوك العدوانى لاى الأطفال المعاقين ذهنيا القابلين للتعلم والممتلكات، وأقل نسبة تحسن بلغت 9.AV\% في متغير السلوك العدوانى نحو الآخرين، بينما جاءت

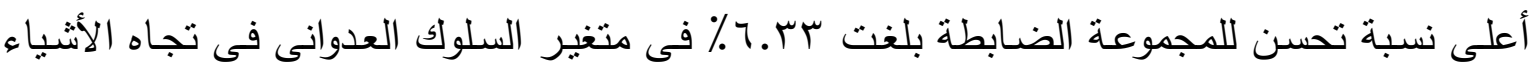
والممتلكات، وأقل نسبة تحسن بلغت 01. ـ ٪ فى متغير السلوك العدوانى نحو الآخرين، وفى المقياس

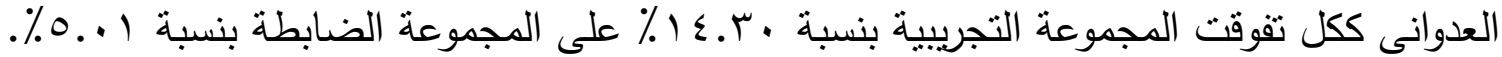
وبذلك يتحقق صحة الفرض الخامس والذى ينص على " توجد فروق ذات دلالة إحصائية في معدل التغير لنسب التحسن بين المجمـوعتين التجريبية والضـابطة فهى بعض المتغيرات البدنيـة ومهارات الكرة الطائرة وخفض حدة السلوك العدوانى قيد البحث لصالح المجموعة التجريبية ".

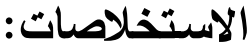

1 - البرنامج الإرشـادى المقترح سـاهم بشكل كبير وفعال فى تتمية بعض المتغيرات البدنية ومهارات الكرة الطائرة لدى أطفال المجموعة التجريبية. r - التعلم بواسطة البرنامج الإرشّادى المقترح أدى إلى نتائج أفضل فى خفض حدة السلوك العدوانى لاى أطفال المجموعة التجريبية. r- الطريقة التقليدية (الثرح اللفظى والاداء النموذج العملى) ساهمت بطريقة ايجابية فى تتمية بعض المتغيرات البدنبـة والمهاريـة فـى الكـرة الطـائرة وخفض حدة السـلوك العدوانى بنسبة أقل مقارنـة بالمجموعة التجريبية. ع - تفوقت المجموعة التجريبية على المجموعة الضـابطة فى معدل التغير لنسب التحسن فى جميع المتغيرات البدنية والمهارية فى الكرة الطائرة قيد البحث وخفض حدة السلوك العدوانى.

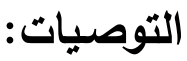
1- ضرورة تطبيق البرنامج الإرشادى المقترح لما أثبته من نتائج فى تحسين المتغيرات البدنية وبعض مهارات الكرة الطائرة لدى أفراد عينة البحث. ז- ضرورة إرشاد وتوجيه المعلم إلى الدور الهام الذى لا يمكن إغفاله فى خفض حدة السلوك العدوانى للأطفال المعاقين ذهنيا القابلين للتعلم بالمرحلة الابتدائية. r- ضرورة إدراج الكثير من البرامج الإرشادية التى تساعد على خفض حدة السلوك العدوانى خلال النشاط الحركى باعتباره من المستحدثات فى مجال النشاط. ع - إجراء المزيد من الدراسات والبحوث التى تربط بين السلوك العدوانى والأداء البدنى والمهارى من خلال استخدام الأساليب التكنولوجية الحديثة. 
- Or -

تأثثير برنامج إرشادى على بعض المتغيرات البذنية والمهارية في الكرة الطائرة وخفض حدة السلوك العدواني لاى الأطفال المعاقين ذهنيا القابلين للتعلم

\section{المراجيع العربيـة والأجنبية

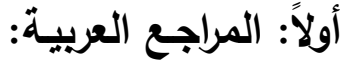

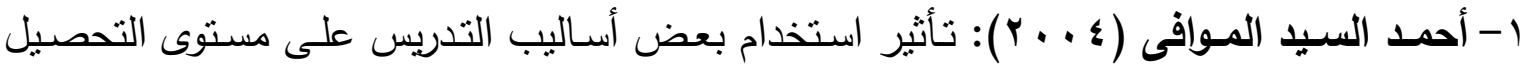
المهارى والمعرفى فى الكرة الطائرة لطلاب كلية التربية الرياضية، رسالة دكتوراه غير اليبر

منشورة، كلية التربية الرياضية، جامعة المنصورة.

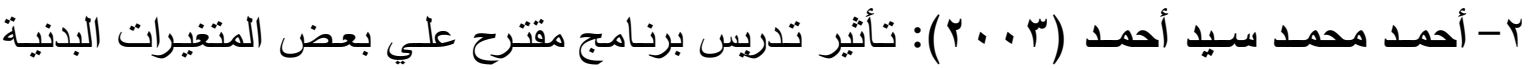

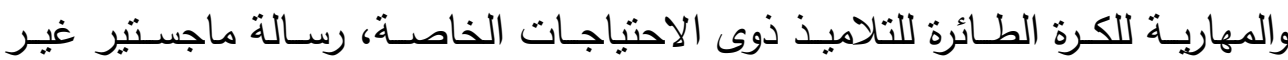

منشورة، كلية التربية الرياضية، جامعة الزقازيق.

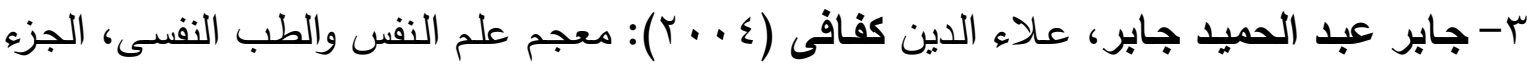
الثانى، طس، مكتبة النهضة، القاهرة.

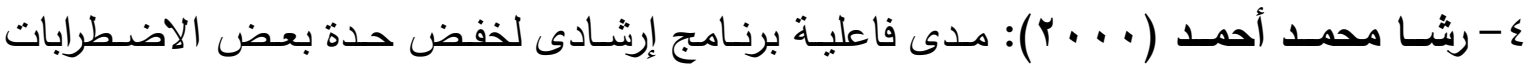
السلوكية لدى الأطفال المعاقين عقلياً فئة القابلين للتعلم، رسالة دكتوراه غير منشورة،

معهد الدراسات العليا للطفولة، جامعة عين شمس.

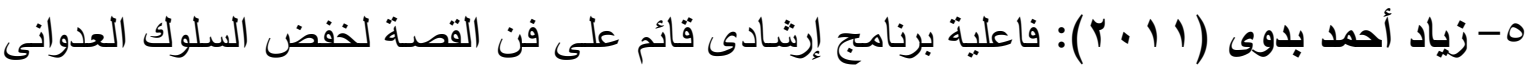
لاى المعاقين عقلياً القابلين للتعلم، رسالة ماجستير غير منشورة، كلية التربية، الجامعة

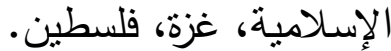

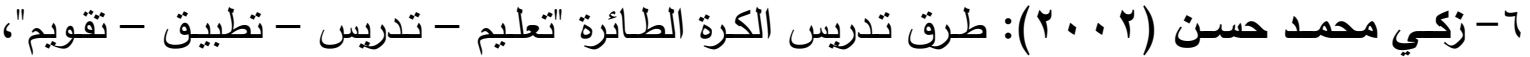
مكتبة ومطبعة الإثعاع الفنية، الإسكندرية.

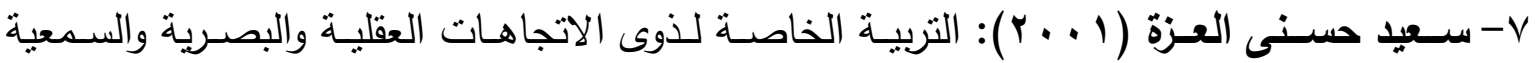
والحركية، الدار الدولية للنشر والتوزيع، عمان، الأردن.

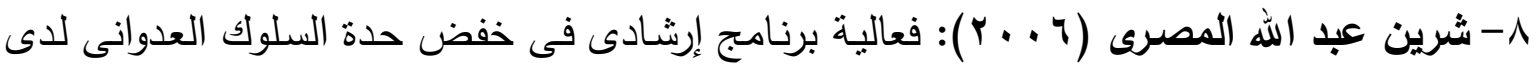
أطفال الرياض بمحافظة غزة، رسالة ماجستير غير منشورة، كلية التربية، جامعة عين النياتئ

9- عايدة شعبان صالح، نور حمودة البنا (^ ـ . ץ): فاعلية برنامج إرشادى لخفض حدة السلوك

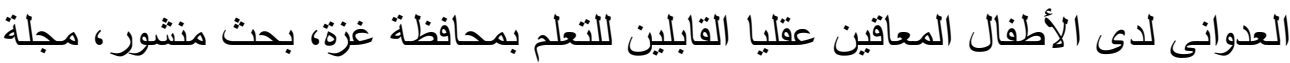
جامعة الأزهر ، سلسلة العلوم الإسلامية، الدجلد العاثر ، العد الأول، غزة، فلسطين.

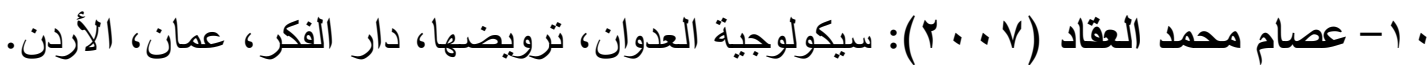
11 لتلاميذ المرحلة الإعدادية بمحافظة قنا، رسالة ماجستير غير منشورة، كلية التربية الرياضية، جامعة أسيوط.

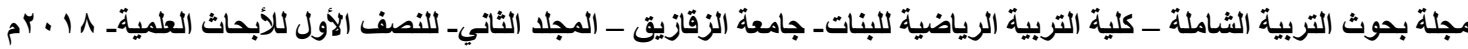


تأثير برنامج إرشادى على بعض المتغيرات البننية والمهارية في الكرة الطائرة وخفض حدة السلوك العدوانى لاى الأطفال المعاقين ذهنيا القابلين للتعلم

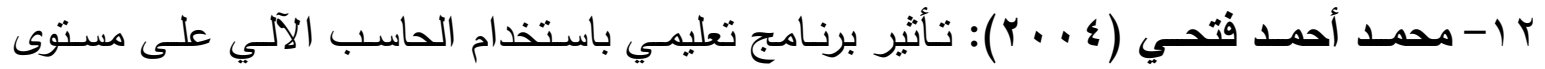

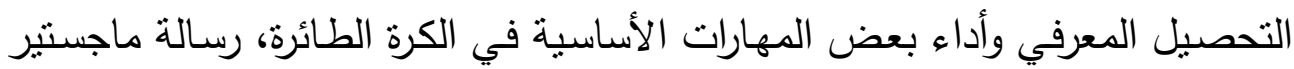
غير منشورة، كلية التربية الرباضية، جامعة المنصورة.

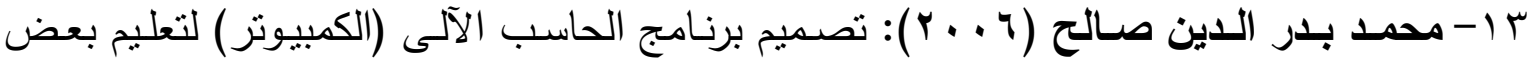

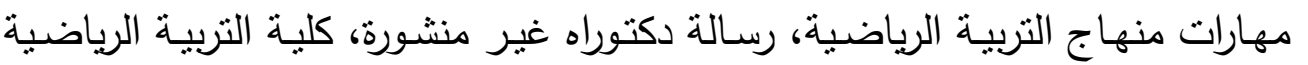

$$
\text { للبنين، جامعة بنها. }
$$

ع ا - محمد صبحى حسانين (1 ( . ب): القياس والتقويم في التربية البدنية والرياضة، طء، دار الفكر العربي، القاهرة.

1 - محمد صبحي حسانين، حمدي عبد المنعم أحمد (99V I ): الأسس العلمية للكرة الطائرة وطرق القياس، دار روزا ليوسف، القاهرة.

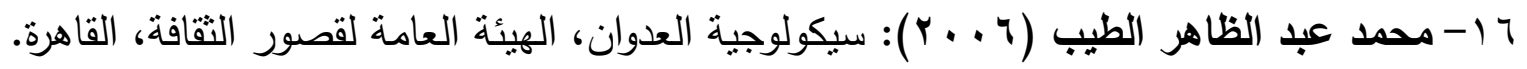

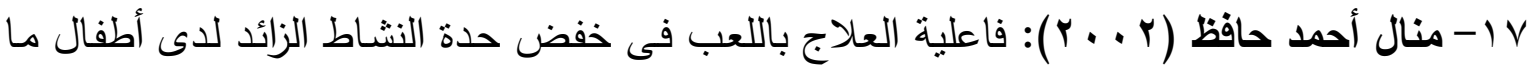
قبل المدرسة، رسالة دكتوراه غير منشورة، كلية التربية، جامعة عين شمس.

ثانياً: المراجع الأجنبيةة:

18- Alvarez Francisco, (2002): The Effectiveness of computer rules, scoring procedures and terminology (tennis), PhD thesis, Florida Stats University

19- Anderson, Micheled. (2003): Picture activity schedules and engagement of andults with mental retardation in a group home research in developmental disabilities, v18, n4.

20-Angorla Scott, (2005): The effects of multimedia tutorials and observation in basketball, New York University.

21- Butter Field, S.A., (2001): In Fluency of ega, sex, hearing loss, and Balance on Development of Running by Deaf children Perceptual and motor skill (missoulammon) 73 (2), 624-626, Oct.

22- Elliott, (2002): Social skill straining for adolescents with intellecninal distillates: cautionary note journals of applied research in intellectual disabilities Vol. (15), Nc (1) 91-96 .

23- Hillier C., Wilkinson Ft., Padfield G., Harrison, (2003): The Effects of volley ball software on female junior high school students, Volley Ball Performance, Physical Educator, 56, No 6.

24- Soucie Katz, L. (2000): The Effectiveness of a computer volleyball program on physical education students planning a volleyball Practice Session the international conference on computer applications in sport and physical education, The Zinman College, Wingate Institute, Netanyahu. 